\title{
Achieving and Maintaining Price Stability in Nigeria
}

Nicoletta Batini 


\title{
IMF Working Paper
}

Research Department

\section{Achieving and Maintaining Price Stability in Nigeria}

\author{
Prepared by Nicoletta Batini ${ }^{1}$ \\ Authorized for distribution by James Morsink
}

June 2004

\begin{abstract}
This Working Paper should not be reported as representing the views of the IMF. The views expressed in this Working Paper are those of the author(s) and do not necessarily represent those of the IMF or IMF policy. Working Papers describe research in progress by the author(s) and are published to elicit comments and to further debate.
\end{abstract}

This paper reviews the historical performance of monetary policy in Nigeria and discusses the relative merits of alternative monetary policy strategies that Nigeria could adopt in the future, once the many operational issues that today obstruct the conduct of monetary policy have been addressed. An analysis of external and fiscal dominance in Nigeria reveals that none of the candidate strategies is particularly appealing although, on various grounds, a long-run target for inflation combined with a free float seems to be the ultimate option. The paper shows how to design and operationalize such a regime in Nigeria when account is taken for the emerging market features of the economy.

JEL Classification Numbers: O23, O24, O55

Keywords: inflation targeting, dollarization, fiscal dominance, Nigeria

Author's E-Mail Address: nbatini@imf.org

\footnotetext{
${ }^{1}$ I would like to thank Bill Allen, Menachem Katz, Jeanne Helen Gobat, Edward Nelson, Steve Nickell, and Geoffrey Wood, and participants at the 2nd Annual Conference on Financial Stability of the Money Market Association of Nigeria, held in Abuja, Nigeria, on May 1-15, 2003, for useful comments on an earlier draft. I am grateful to Stuart Lee and Imran Contractor for excellent research assistance. All errors and omissions are mine.
} 
Contents

Page

I. Introduction 4

II. A Brief History of Inflation in Nigeria: 1980-2003 ................................................4

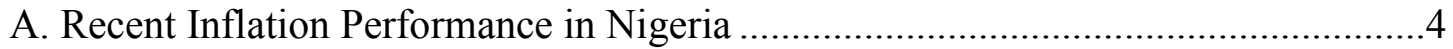

B. Viable Monetary Policy Strategies for Nigeria ..................................................... 7

III. Stylized Facts on Nigeria's External Dominance and Monetary Transmission .................9

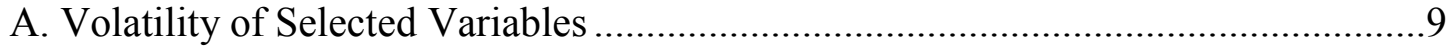

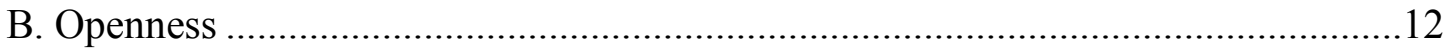

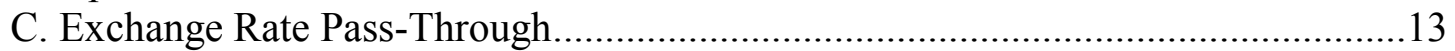

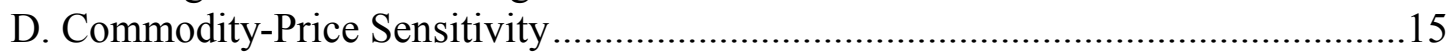

E. Fiscal Sustainability and Risk Premia on Sovereign Debt ................................. 16

IV. A Way Ahead for Monetary Policy in Nigeria? ...................................................... 18

V. Opting for Price Stability in Nigeria ....................................................................22

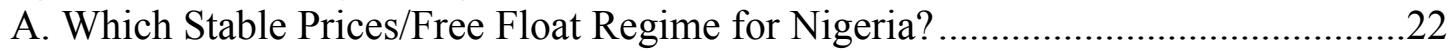

B. A Target for Stable Prices in Nigeria ................................................................24

VI. Operationalizing Price Stability in Nigeria via a Simple Plan .....................................26

A. How Should Taylor Rules be Used in Emerging Market Economies? ....................28

VII. The Historical Taylor-Rule-Implied Path for Nigeria .............................................30

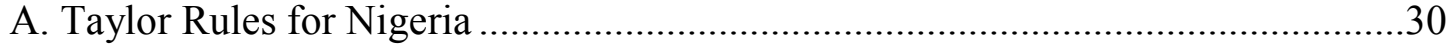

B. Taylor Rules for Other Emerging Market Economies ........................................32

VIII. Concluding Remarks and Policy Implications .......................................................34

Tables

1. Volatility and Average of Selected Variables for 1997 Q1-2002 Q2 …...................10

2. Total Trade-to-GDP Ratios, Selected Emerging Market Economies .........................13

3. Variance Error Decomposition (4-, 8-, and 12-quarter horizon) ...............................14

4. $\quad$ Emerging Markets Bond Index+ (EMBI+) ....................................................... 17

Figures

1. Nigeria: Annual CPI Inflation, Output Gap, and Nominal Interest Rate.....................5

2. Nigeria: Fiscal Trends and Oil Price....................................................................6

3. Inflation-Output Volatility Trade-Offs, Inflation-Targeting Developed

Economies, and Emerging Market Economies and Nigeria .................................11 
Figures (cont.)

4. Nigeria's Nominal Effective Exchange Rate (in logs): 1990 Q1-2002 Q4...............20

5. Nigeria Minimum Rediscount Rate (MRR) vs. Taylor-Rules-Implied Rates .............31

6. Chile: Actual Nominal Rate vs. Taylor-Rules-Implied Rates ...................................33

7. Brazil: Selic Rate vs. Taylor-Rules-Implied Rates .............................................33

8. South Africa: Actual Nominal Rate vs. Taylor-Rules-Implied Rates.........................34

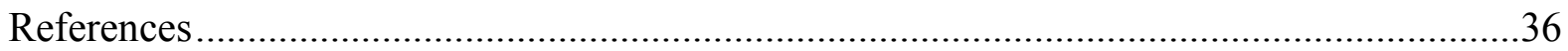




\section{INTRODUCTION}

To date, the implementation of monetary policy in Nigeria has been complicated by a number of factors, including fiscal largesse, lack of operational autonomy of the central bank, insufficient and low-quality statistics, a weak transmission mechanism, and a weak financial system. This paper investigates whether, were all these factors to be successfully addressed, announcing and pursuing a long-run target for inflation would be a good monetary policy strategy for Nigeria. The paper also examines whether in Nigeria this strategy would be superior to the alternative of fixing the exchange rate.

To this end, the paper analyses the sensitivity of Nigeria to external shocks and looks at other relevant characteristics of the Nigerian economy by examining a set of stylized facts. Throughout, Nigeria's stance is judged against that of other emerging market economies or developed economies that, in recent years, have opted for and succeeded in (with some qualifications) achieving price stability under a free float.

The analysis reveals that neither the stable prices/free float nor the fixed exchange rate solutions are particularly appealing for Nigeria in the long run. However, inflation targeting with a free float still seems to be a superior option on various grounds. Results also suggest that, if over the past 20 years, the Central Bank of Nigeria (CBN) had been granted independence in setting monetary conditions and had followed a Taylor rule consistent with a single-digit inflation target, monetary conditions might have been less accommodative and, hence, inflation in Nigeria might have been lower and less volatile than what was observed.

The plan of the paper is as follows. Section II gives a brief account of the history and possible causes of inflation in Nigeria over the past two decades and then looks at viable monetary policy strategies for the future. Section III presents evidence on Nigeria's transmission mechanism susceptibility to external shocks, and Sections IV and V discuss what the results imply for the choice of a monetary policy strategy. Section VI focuses on operational issues, such as the choice of a simple plan that can help guide monetary setting. Finally, Section VII compares actual monetary conditions in Nigeria and other emerging market economies with conditions implied by a simple reaction function consistent with a single-digit inflation target. Concluding remarks and policy implications follow in Section VIII.

\section{A BRIEF History OF INFLATION IN NigERIA: 1980-2003}

\section{A. Recent Inflation Performance in Nigeria}

Throughout the past two decades, the objectives of Nigerian monetary policy have been the attainment of internal and external balance. This was reaffirmed by the CBN Monetary Policy Circular No. 33, 2002, stating that one of the CBN's major objectives is the "sustenance of price and exchange rate stability." This remit is analogous to that of many developing countries, which, on the one hand, see the benefits of stabilizing domestic prices 
and, on the other hand, value the necessity of keeping the exchange rate fairly stable — being usually open and importing nations.

Despite the apparent continuity in objectives, Nigeria's inflation experience since 1980 has been mixed. Figure 1, plotting year-on-year changes in the Nigerian CPI (D4CPI) for the last 20 years, emphasizes this point. The figure shows that in the period from the early 1980 s to the second half of the 1990s, annual inflation has averaged around 30 percent.

Subsequently, average annual inflation has come down to one-digit rates. However, since 2001 , inflation is back in the two-digit rate territory, with an average of about 18 percent over 2000-2002. Although the IMF and EIU penciled in an inflation forecast of 12-14 percent for 2003, others, including Standard Chartered, have forecasted prices to continue growing at around 19 percent on a year-on-year basis for that year. ${ }^{2}$

Figure 1. Nigeria: Annual CPI Inflation, Output Gap, and Nominal Interest Rate

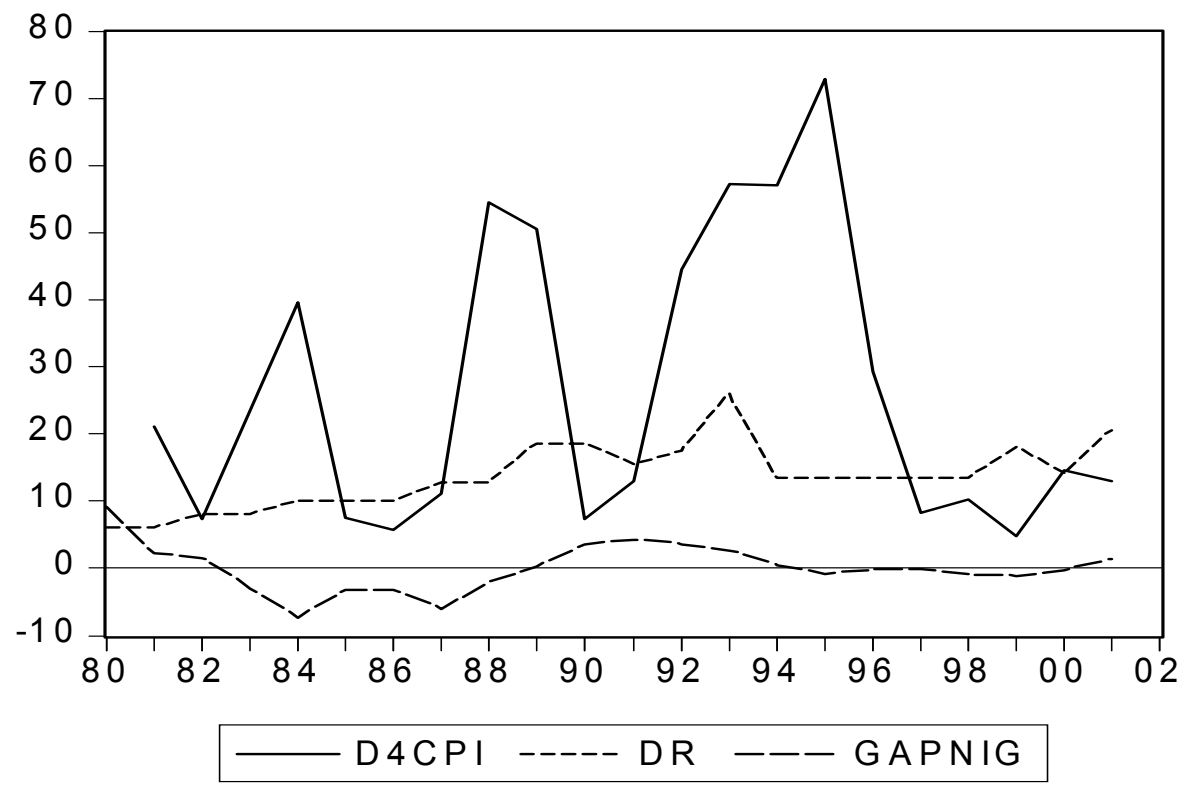

One often cited explanation for Nigerian inflation performance since 1980 rests with the weaknesses in Nigerian fiscal policy framework over this period. Nigeria is an oil exporter and fiscal revenue throughout the past two decades has largely coincided with oil revenue (see Figure 2). ${ }^{3}$ Naturally, oil revenue is very volatile due to wild oscillations in oil's spot and future US\$ price per barrel and to unpredictable changes in OPEC assigned oil quotas_ of which Nigeria has been a member since 1958 following the commercial

\footnotetext{
${ }^{2}$ See Standard Chartered (2003).

${ }^{3}$ In Nigeria oil extraction accounts for 40 percent of GDP, 70 percent of government revenue, and 95 percent of foreign exchange earnings. See McPherson (2002).
} 
discovery of oil in Oloibiri, in Nigeria's Rivers State, in 1956. OPEC quotas are in fact frequently adjusted in an attempt to raise or lower the cartel's equilibrium price of crude oil internationally.

Figure 2. Nigeria: Fiscal Trends and Oil Price ${ }^{4}$

(In percent of GDP, unless otherwise stated)

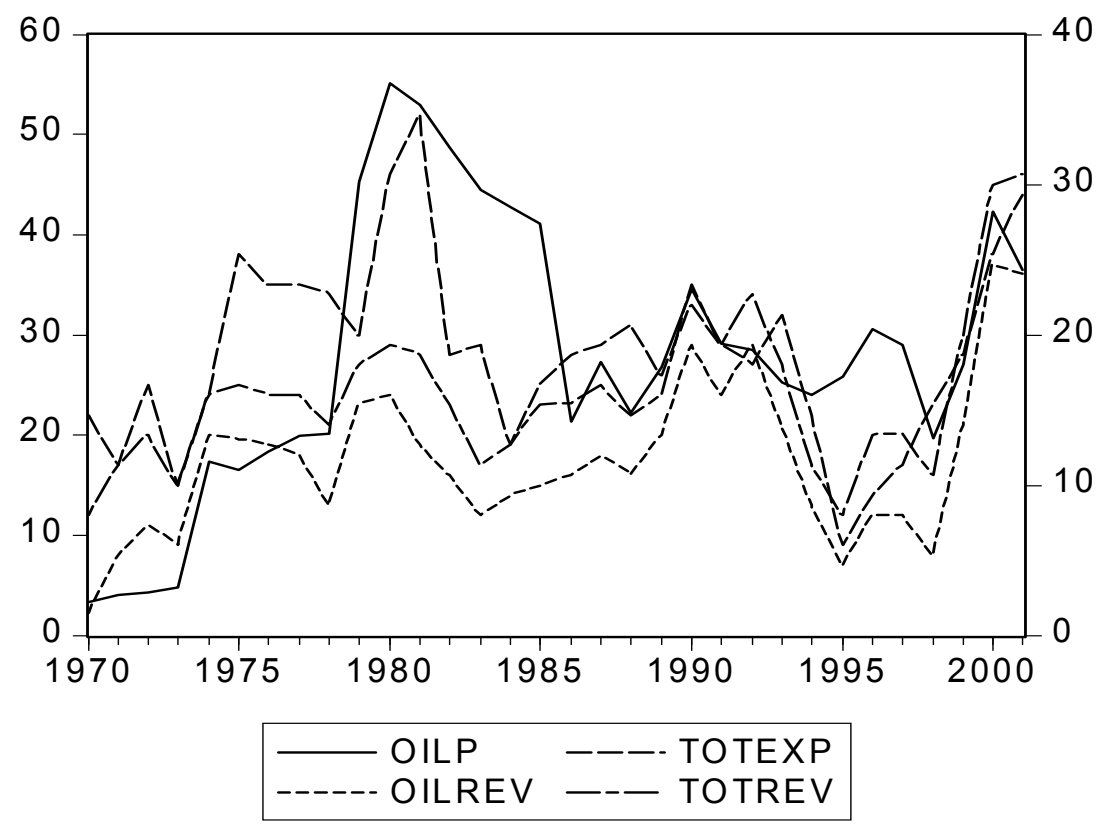

Absent suitable fiscal rules and a proper finance-management framework for oilrelated risks, Nigeria's variable oil and fiscal revenues in the 1980s and 1990s have led to boom-and-bust-type fiscal policies that have generated large and unpredictable movements in government deposits and ways and means account. ${ }^{5}$ These, in turn, have been a recurrent source of liquidity surprises and have instilled significant volatility in the Nigerian financial

\footnotetext{
${ }^{4}$ Notation in Figure 2 is as follows: OILP = oil price per barrel (future in US\$); OILREV = oil revenue; TOTEXP = total oil exports; TOTREV = total fiscal revenue.

${ }^{5}$ Katz (2003) emphasizes that fiscal procyclicality and poor quality of public expenditure in Nigeria have also led to negligible PPP per capita income growth in Nigeria since 1980. This is the case also in other oil-producing developing countries sharing the same weaknesses (notably Venezuela and Algeria) that have seen similarly low income growth per capita over this period. Yet it is not the case in countries that have implemented sound fiscal policies oriented toward macroeconomic stability (for example, Indonesia).
} 
system. ${ }^{6}$ As discussed later, the combination of liquidity surprises with the ability of the federal government to finance large budget deficits by borrowing freely from the CBN at below market-clearing interest rates has severely impaired the CBN in its conduct of shortrun and long-run strategy during the past two decades, and has indeed been a major driver of the unstable evolution of inflation since 1980.

A second possible explanation for the varied inflation performance in Nigeria can be found in the recent literature on monetary regimes for open economies. A key notion arrived at in this literature is that it is not possible for a country open to international capital flows like Nigeria to have both a stable exchange rate and monetary policy directed at domestic goals like price stability - the so called "impossible trinity" (see Fischer, 2001). Sooner or later conflicts between the two goals arise, jeopardizing the attainment of one or even both objectives. One particular aspect of the debate is that trying too hard to keep exchange rates stable when the economy is open and subject to short-term capital flows can be risky. International evidence confirms this notion. As stressed in Fischer (2001), for example, each of the major international capital market-related crises (e.g. Mexico in 1994; Thailand, Indonesia, and Korea in 1997; Brazil and Russia in 1998; and Argentina and Turkey in 2000) involved some sort of fixity of the exchange rate.

As a result, a consensus appears to have now emerged that adjustable pegs and other soft pegs (including, arguably, managed floats explicitly directed at maintaining the exchange rate around a certain level, such as in the case of Nigeria), can be dangerous arrangements for open economies subject to international capital flows (see, for instance, Khan, 2003). Viable alternatives boil down to the "corner solutions" of either completely giving up monetary policy and national currencies by evolving toward official dollarization/euroization (basically a form of unilateral currency union) or strengthening national currencies by use of an inflation target combined with a float. ${ }^{7}$

\section{B. Viable Monetary Policy Strategies for Nigeria}

Amid the current debate on sustainable monetary policy regimes for open, emerging market economies, and considering its mixed inflation record and its fiscal situation, what is the best long-run monetary regime solution for Nigeria?

Nigeria's exchange rate arrangement is a managed float, according to the IMF member countries' exchange rate regime classification (see Fischer, 2001). More specifically, in July 2002; Nigeria reintroduced a bi-weekly Dutch Auction System (DAS) as an operational system for its foreign exchange market to replace the Interbank Foreign

\footnotetext{
${ }^{6}$ Intergovernmental relations at the state and local levels have tended to complicate macroeconomic management because they typically trigger further uncontrollable fiscal imbalances.

${ }^{7}$ After the current crisis in Argentina, pegging the national currency hard, via a currency board, for example, seems to have become one of many monetary regimes on their way out.
} 
Exchange Market (IFEM). The DAS is a method of exchange rate determination through auction where bidders pay according to their bid rates and where the ruling rate is arrived at with the last bid rate that clears the market. In short, contrary to the old IFEM system, where supply of currency was elastic at some given rate, take or leave some allowance for depreciation when demand was perceived to be too large, under the DAS the exchange rate is mainly determined by the bids made by commercial banks on behalf of their clients. So the move back to a DAS indicates that Nigeria seems to be wishing for more, rather than less, flexibility in the exchange rate and leads one to think that Nigeria appears to be opting for the last monetary regime solution: stable prices and a freely floating exchange rate. This raises two considerations.

First, in order to be able to effectively pursue this monetary regime - or any other for that matter-Nigeria must initially address a number of institutional and operational issues (see Batini and Gobat, 2004). These include designing a workable fiscal-monetary policy mix so that the borrowing requirements of the government no longer dominate monetary policy decisions. This includes granting operational autonomy to the $\mathrm{CBN}$ so that the government can no longer interfere with monetary policy operations, while providing an adequate system of checks and balances to ensure central bank accountability; developing macroeconomic statistics that are timely and consistent; documenting the monetary transmission mechanism; and operating measures that can strengthen transmission as well as the financial system at large, including a reform of the foreign exchange rate market that prevents the existence of multiple markets.

Second, even once these issues have been addressed, it is not clear whether stable prices and a freely floating exchange rate, for example, in the form of a regime of inflation targeting, would be a superior option in the long run to fixed exchange rates in an open, emerging market economy like Nigeria. As recently pointed out by a number of authors, there are, in fact, distinctive issues about inflation targeting in open economies. ${ }^{8}$ These include susceptibility to external shocks and the sensitivity of output and inflation to the exchange rate, i.e., the extent of "external dominance." There are also distinctive issues about inflation targeting in emerging markets relating to credibility, fiscal dominance, and soundness of the financial system.

A rigorous assessment of the suitability of the former solution for Nigeria would thus hinge on an analysis of, inter alia: (i) the degree of openness of the Nigerian economy; (ii) the extent to which changes in the exchange rate are "passed through" into domestic prices; (iii) the extent of existing indexation in price and wage contracts; (iv) the potential ability of the CBN to forecast inflation, given the traditional long and variable lags between monetary policy impulses and inflation; (v) the degree of commodity-price sensitivity of Nigerian consumer price inflation; (vi) the sensitivity of domestic financial conditions to international capital flows; (vii) the extent of liability dollarization/euroization; (viii) the

\footnotetext{
${ }^{8}$ See, for example, Eichengreen, Masson, Savastano, and Sharma, 1999; Schaechter, Stone and Zelmer, 2000; and Eichengreen, 2002.
} 
credibility of the central bank; ${ }^{9}$ and again (ix) the severity of "fiscal dominance" and the soundness of the financial sector.

\section{Stylized FaCts On Nigeria’s EXTernal Dominance AND Monetary TRANSMISSION}

To gauge whether Nigeria's revealed preference for a stable prices/free float regime is in principle an appropriate choice for the longer run, this section reports evidence on a subset of stylized facts about Nigeria's susceptibility to external shocks and other key aspects characterizing its monetary transmission. All along, these are compared to similar facts for a group of emerging market economies and developed economies pursuing stable prices under free floats. Although this subset is a far from an exhaustive list of possible things to look at, it can give a feel for how "well poised" Nigeria is to adopt a monetary policy regime that emphasizes price stability at the expense of exchange rate stability. In a restrictive sense, this exercise is similar to one addressing the question, "Will inflation targeting work in Nigeria?"

\section{A. Volatility of Selected Variables}

The reason why emerging market economies explicitly concerned with price stability usually perform less well than developed economies in terms of price and/or inflation stabilization can be attributed to the fact that stabilizing prices is harder for emerging market economies. ${ }^{10}$ This is because emerging market economies face a more volatile macroeconomic environment and, typically, have weaker institutions that enjoy less credibility than their developed economies' counterparties. Importantly, the volatility of macrovariables and the authorities' credibility are related, in the sense that emerging market economies find it more difficult to acquire credibility in an unstable environment. In turn, this leads to unstable outcomes, which undermine the credentials of the monetary authorities.

Does Nigeria face a volatile macroeconomic environment? And, if so, is this environment more volatile than the ones faced by other emerging market economies that have successfully embraced a stable prices/free float regime, for example, Chile? Table 1 summarizes differences in macrovariability by listing volatilities of consumer price annual inflation, the nominal effective exchange rate, GDP growth, and the short-term nominal interest rate for a group of inflation targeting developed economies and a group of inflation targeting emerging market economies ${ }^{11}$ from 1997 Q1 to 2002 Q2 - a recent period which

\footnotetext{
${ }^{9}$ Kumhof (2000) explores what happens when the public (correctly) believes that inflation targeting will not last.

${ }^{10}$ Annual inflation in developed economies that target inflation dropped on average from 3.7 percent to 2.5 percent after the adoption of the targets (up to 2002 Q2). Results in emerging market economies were also positive but not as good, with year-on-year inflation falling to 5.95 percent on average from 13.11 percent before and after the introduction of explicit targets for inflation.

${ }^{11}$ The multi-dimensional nature of what defines an inflation-targeting regime implies that there is no consensus on which countries are inflation targeters. So the list of inflation
} 
includes the Asian, Brazilian and Russian crises. It also shows averages of consumer price annual inflation and real output growth for all these countries, including corresponding statistics for Nigeria.

Table 1. Volatility and Average of Selected Variables for 1997 Q1-2002 Q2

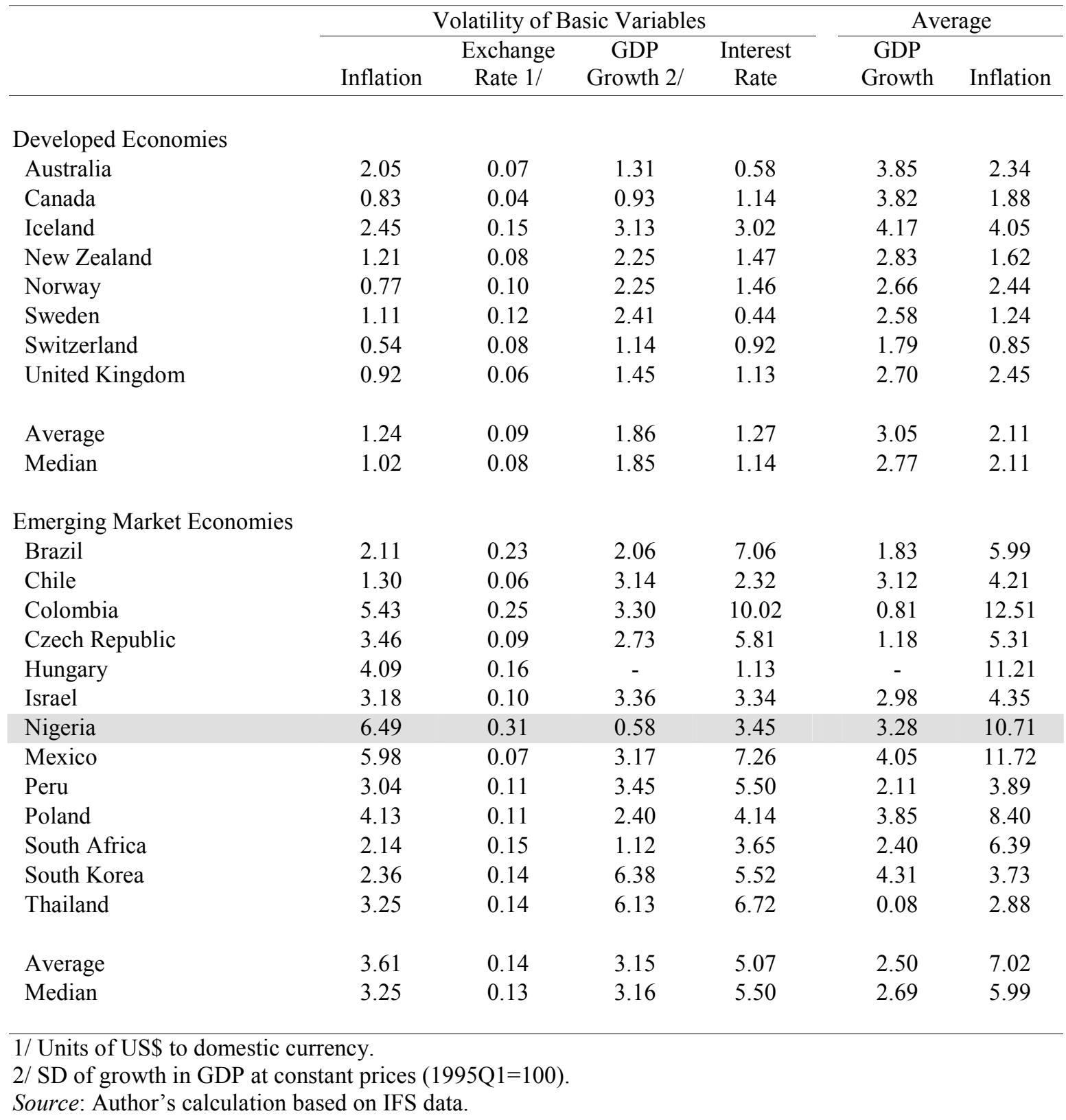

targeting countries changes frequently. Mishkin and Schmidt-Hebbel (2001) identify the precise features that should be taken to characterize an inflation-targeting regime. 
As expected, the table indicates that on average the volatilities of inflation, output, and financial prices are higher in emerging market economies than in developed economies. In addition, average inflation is higher and average output growth lower in emerging market economies relative to developed economies. Among emerging market economies, Nigeria exhibits the highest inflation and exchange rate variability, the lowest output volatility, and an interest rate volatility that is slightly smaller than that of South Africa and much smaller than that of Brazil, but slightly larger than that of Chile. Nigeria's average inflation over this period is the fourth highest in the emerging market economies group, following Colombia, Mexico and Hungary. On the other hand, Nigeria's GDP growth is one of the most buoyant among emerging market economies, second only to South Korea, Mexico, and Poland, which all grew on average around 4 percent a year between 1997 and 2002.

In short, Nigeria seems to face a macroeconomic environment that is indeed more volatile than say, Brazil, Chile, and South Africa, at least in terms of inflation and exchange rates. Figure 3 emphasizes this point by showing that Nigeria faces a more acute inflation-

Figure 3. Inflation-Output Volatility Trade-Offs, Inflation-Targeting Developed Economies, and Emerging Market Economies and Nigeria

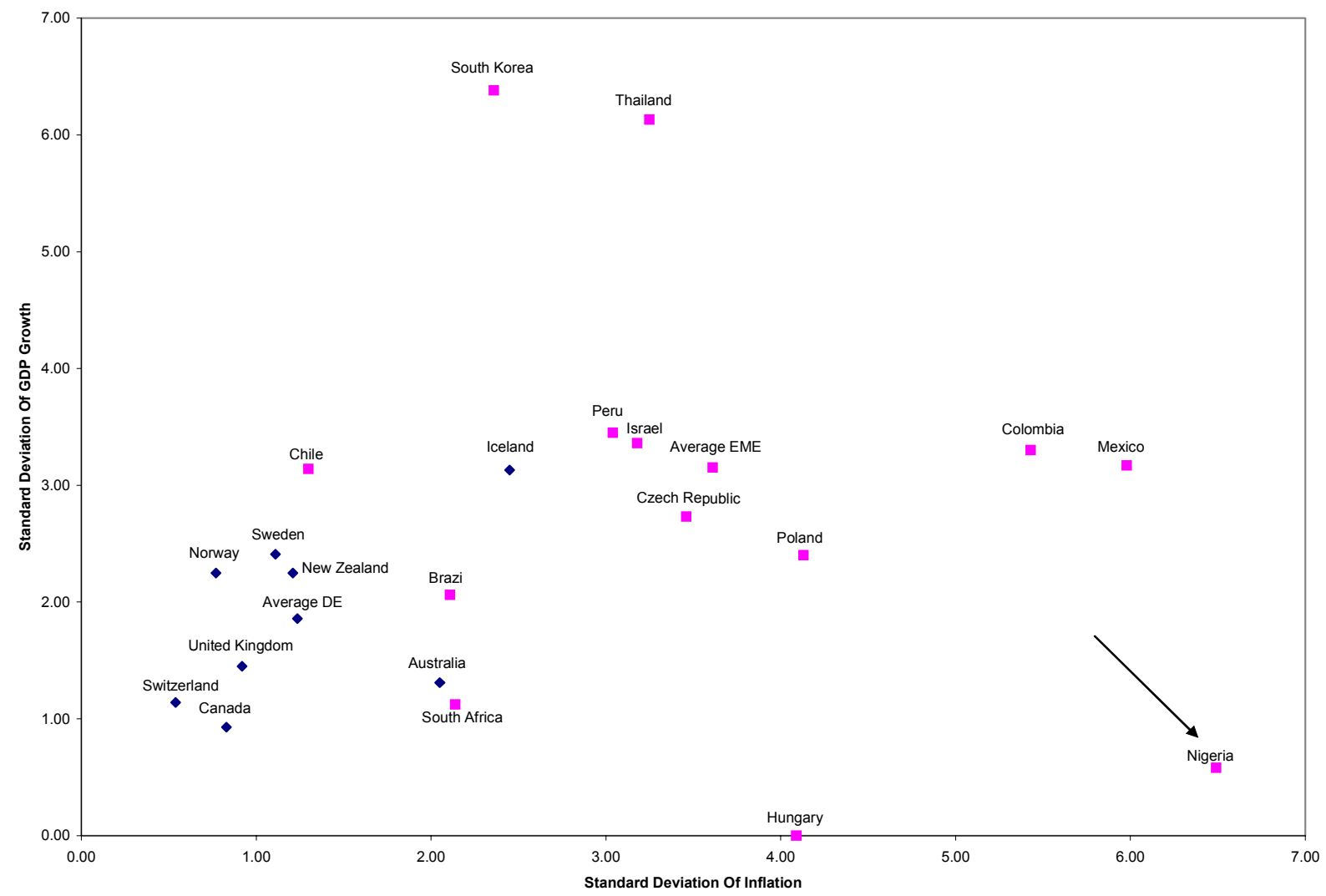

Note: Squares indicate emerging market economies (EME). Diamonds indicate developed economies (DE).

output volatility trade-off than most emerging market economies and developed economies engaged with active price stabilization under floating exchange rates. This weighs negatively toward the ability to implement a stable prices/free float regime in Nigeria, because it means it may be hard for Nigeria to successfully stabilize prices and build the necessary anti- 
inflation credentials to maintain these stable over time. At the same time, it could be argued that Brazil, Chile, and South Africa face less variability in nominal macrovariables precisely because they have embarked onto price stabilization programs during the period analyzed here. Nigeria's inflation and exchange rate volatility may fall as a consequence of a similar regime move if this was perceived by the public to be a true shift in preferences on the side of the government - in other words, volatility is endogenous to the monetary policy regime chosen, as stressed in Taylor (2000a).

\section{B. Openness}

Perhaps the simplest measure of openness of a country is given by the ratio of total trade to GDP. ${ }^{12}$ The degree of openness of a country matters in the choice of a monetary policy regime because openness subjects the economy to both commodity and financial market shocks and it introduces additional channels for policy. This may complicate the achievement of stable prices. In particular, since the optimal monetary policy response depends on the source of shock, openness requires that the monetary authority be able to discern between international commodity shocks and shocks to financial markets. ${ }^{13}$ Besides, in an open economy a rise in interest rates not only reduces investment via the direct output gap channel, but it also depresses net export demand via the appreciation of the exchange rate. So openness makes responding to aggregate demand shocks more difficult (see Batini, Harrison, and Millard, 2003).

Table 2 lists ratios of total trade (average imports of goods and services plus exports of goods and services) to GDP in three inflation-targeting emerging market economies and compares them with ratios for Nigeria over different samples. Nigeria appears to be the most open economy within the group according to this measure: at around 70 percent, the average ratio of total trade to GDP in Nigeria in the past 5 to 10 years is almost three times as large as that observed in Brazil and Chile and a third larger than the South African ratio. Such a high interchange with the rest of the world suggests that the Nigerian economy is naturally strongly exposed to external shocks, like shocks to commodity prices, exchange rates and/or relative prices of imported intermediate and final goods - which may reduce the ability of the central bank to control domestic variables. So pursuing price stability in Nigeria may be complex, perhaps more so than in other emerging market economies that have recently adopted explicit targets for inflation and that are less open.

${ }^{12}$ However, this measure only quantifies openness to trade flows, ignoring openness to capital flows which is also important in emerging market economies.

${ }^{13}$ Optimal policy also depends on the duration of the shock, i.e. on whether the shock is permanent or temporary. 
Table 2. Total Trade-to-GDP Ratios, Selected Emerging Market Economies

\begin{tabular}{lcccc}
\hline & Brazil & Chile & Nigeria & South Africa \\
\hline & & & & 0.69 \\
Average Past 5 years & 0.24 & 0.21 & 0.63 & 0.55 \\
Average Past 10 years & 0.20 & 0.15 & 0.70 & 0.59 \\
Memo: 1997-2002 & 0.23 & 0.20 & & \\
\hline
\end{tabular}

Source: Author's calculation based on IFS data.

\section{Exchange Rate Pass-Through}

Calvo and Reinhart (2000) find that exchange rate pass-through, namely, the amount of exchange rate change that translates into changes in import prices and hence consumer price inflation, is higher in emerging markets. They rationalize this in two ways: (i) in emerging market economies high inflation in the past has induced widespread wage and price indexation. So changes in CPI due to exchange rate changes are fully and automatically locked in future wage and price inflation; (ii) emerging market economies' central banks are less credible. This leads one to believe that temporary shocks to the exchange rate will be accommodated and hence become permanent, and so these shocks indeed affect inflation permanently via second round effects.

Rapid exchange rate pass-through modifies the implementation of monetary policy. In particular, it amplifies the dangers of conducting monetary policy in an open economy. Yet, like macroeconomic volatility — of which it is a driver - pass-through is not exogenous. If policy is credible and transparent in its pursuit of price stability, transitory shocks may not be passed onto inflation permanently.

In order to quantify the importance of pass-through and the impact of external shocks in a subgroup of emerging market economies committed to price stability under a flexible exchange rate regime and compare these to the Nigerian case, Vector Autoregressions for Brazil, Chile, Nigeria, and South Africa and for a set of inflation-targeting developed economies are estimated. ${ }^{14}$ Throughout, data are quarterly and over the period 1990 Q1 to 2002 Q4 for four variables, namely: consumer price inflation; (log) real output in deviations from a Hodrick-Prescott trend with smoothing parameter $\lambda=1,600$; levels or changes (i.e. $\log$ level or log first difference) of the nominal effective exchange rate; and the short-term nominal interest rate. ${ }^{15}$ The innovations are identified using a Choleski decomposition with

${ }^{14}$ Lag-length was 2,2,2,2, respectively, in line with results from various lag-length criteria.

${ }^{15}$ All data are from the IMF's International Financial Statistics. For the Nigerian nominal interest rate, the end of period value of the discount rate is used. Annual Nigeria GDP data at factor costs has been interpolated to obtain a quarterly series. For Chile, the monetary policy rate of the Central Bank of Chile from 1995 Q1 onwards is used, spliced with the indexed Chilean deposit interest rate 90 to 365 days for the period between 1990 Q1 and 1994 Q4. 
the causal ordering: exchange rate $\rightarrow$ output gap $\rightarrow$ inflation $\rightarrow$ interest rate, which ensures that the interest rate is the only variable responding contemporaneously to monetary policy shocks. Subsequently, variance error decompositions for inflation in each VAR were calculated. These separate the variation in inflation into the component shocks to the VAR, thus providing information about the relative importance of each random innovation in affecting inflation. Of particular interest here is the percentage of the forecast error of inflation that is explained by shocks to the exchange rate.

Table 3 records the values of the error decomposition of inflation considering a 4-, 8-, or 12-quarter horizon. The table reports findings for both the case when the level and the change in the exchange rate in the VARs are used. Unsurprisingly, in the case of emerging market economies, shocks to the exchange rate explain a much more significant part of the

Table 3. Variance Error Decomposition (4-, 8-, and 12-quarter horizon)

\begin{tabular}{|c|c|c|c|c|c|c|}
\hline & \multicolumn{3}{|c|}{ VAR with Exchange Rate in Levels } & \multicolumn{3}{|c|}{ VAR with Exchange Rate in First Differences } \\
\hline & 4-quarter & 8-quarter & 12-quarter & 4-quarter & 8 -quarter & 12-quarter \\
\hline \multicolumn{7}{|l|}{ Emerging Market } \\
\hline \multicolumn{7}{|l|}{ Economies } \\
\hline Brazil & $58^{*}$ & $44^{*}$ & $38^{*}$ & $79^{*}$ & $75^{*}$ & $78^{*}$ \\
\hline Chile & 1 & 2 & 4 & 3 & 3 & 2 \\
\hline Nigeria & 1 & 14 & 17 & 3 & $88^{*}$ & $87 *$ \\
\hline South Africa & 4 & 3 & 5 & 18 & 16 & 15 \\
\hline \multicolumn{7}{|l|}{ Developed } \\
\hline \multicolumn{7}{|l|}{ Economies } \\
\hline Australia & 12 & & 3 & 1 & & 11 \\
\hline Canada & 0 & & 1 & 2 & & 2 \\
\hline New Zealand & 1 & & 0 & 5 & & 1 \\
\hline Sweden & 4 & & 1 & 4 & & 10 \\
\hline United Kingdom & 0 & & 0 & 1 & & 1 \\
\hline
\end{tabular}

Note: * indicates significance at the 5 percent level.

forecast error in inflation than is the case for developed economies. Out of the four emerging market economies considered here, for Brazilian data the exchange rate explains between 38 percent and 79 percent of inflation forecast errors at various horizons under either VAR specification. The exchange rate is also significant in explaining around 90 percent of Nigerian inflation considering 8- or 12-quarter horizons, when first differences of the exchange rate in the VAR are used. On the contrary, exchange rate shocks are not significant in explaining errors for other emerging market economies' inflations (or, indeed, those of developed economies) and in general do not play an equally important part.

This result suggests that inflation in Nigeria may be highly influenced by fluctuations in the international value of the naira as these translate directly-albeit with long and

For Brazil, the Brazilian overnight federal funds rate or SELIC is used. Finally, for South Africa, the prime overdraft rate is used. 
variable lags - onto consumer price changes. With high pass-through, inflation may be harder to control in Nigeria relative to South Africa, say, even if South Africa is a highly open economy and if the South African rand is quite volatile relative to other emerging market economies' currencies. Since higher pass-through implies that external shocks translate easily onto domestic variables, Nigeria may find it harder than other emerging market economies to build credibility in the process toward price stabilization. Importantly, high pass-through also means that Nigeria will be more inclined to attempt to regularly stabilize the exchange rate by intervening in the exchange rate market - the consequence of what Calvo and Reinhart (2000) dub "fear of floating."

\section{Commodity-Price Sensitivity}

Emerging market economies do not just face higher degrees of pass-through than developed economies. Usually they are also more sensitive to changes in commodity prices than their advanced industrial counterparts. This is because, typically, emerging market economies' main exports are homogenous commodities traded in perfectly competitive markets. A change in their foreign-currency price can thus greatly affect their demand because this is infinitely elastic. Fluctuations in commodity prices add to the volatility of domestic output and inflation and affect the exchange rate via their impact through the current account. This makes it more difficult to forecast and so to control inflation, which in turn damages credibility as it raises doubt about the seriousness of the central bank vis-à-vis its commitment to price stability.

Is Nigerian CPI particularly sensitive to commodity price shocks, for example, shocks to the price of oil? Oil, by far Nigeria's main export, accounts for 40 percent of Nigerian GDP and 95 percent of foreign exchange earnings. This is in line with other oil-exporting countries, like, for example, Algeria, where oil accounts for 30 percent of GDP and 80 percent of foreign exchange rate earnings (see McPherson, 2002). So it is reasonable to expect that a shock to the price of oil should have a significant impact on Nigerian GDP and, therefore, on Nigerian inflation.

To quantify the sensitivity of Nigerian CPI to changes in commodity prices, the variance error decomposition analysis above for Nigeria was re-run, this time including the first difference of the log price of oil in US\$ among the regressors. For comparability, the variance error decomposition for South Africa, historically a strong gold exporting country, was also re-run, including the first difference in the US\$ price of gold among the regressors. 16

Results (not reported in Table 3) show that changes in the price of oil explain (but not significantly) 13 percent, 15 percent, and 15 percent of forecast errors in the Nigerian CPI inflation at 4-, 8-, and 12-quarter horizons, respectively (the corresponding percentages for the output gap are 1 percent, 0 percent, and 2 percent). By contrast, changes in the price of

${ }^{16}$ South Africa's share of gold exports to total exports was about 56 percent in 1970 . It fell to just around 11 percent in 2002. 
gold explain (this time significantly in the 12-quarter case) 16 percent, 16 percent, and 22 percent of forecast errors in South African CPI inflation at 4-, 8-, and 12-quarter horizons, respectively (the corresponding percentages for the output gap are 2 percent, 8 percent, and 31 percent).

According to these findings, it thus looks as if Nigerian CPI inflation is not too sensitive to the price of oil, its main exporting commodity. Nigeria also seems less sensitive to commodity price changes than, say, South Africa - another emerging market economy that opted for a stable prices/free float regime_- even if the latter's share of commodity exports to total exports is much smaller than that of Nigeria. One explanation for this may be that Nigeria is more sensitive to changes in the quantity of oil exported (i.e., the OPEC quota) rather than to changes in its international price. The lack of sensitivity of Nigeria's inflation to the price of its main export means that fluctuations in the price of oil may not be a severe hindrance to attempts of the central bank to stabilize the consumer price level around a certain growth rate.

\section{E. Fiscal Sustainability and Risk Premiums on Sovereign Debt}

As highlighted in the previous section, the fiscal position of a country is important in determining whether a country not choosing to "permanently" fix the exchange rate may safely adopt an explicit goal for price stability. Examining in depth the fiscal stance of Nigeria, and exploring whether - and if so over which horizon - it is possible to reform the Nigerian fiscal system, is beyond the scope of this paper. It is interesting, however, to look at least at one variable that matters in this respect, namely, a variable that summarizes on a daily basis what investors think about the state of the Nigerian economy: the Nigerian component of the Emerging Market Bond Index, the EMBI+ spread, computed by J.P. Morgan. ${ }^{17}$

The EMBI+ spread measures the difference between the yield of a dollardenominated bond issued by a non-U.S. emerging market economy over a corresponding bond issued by the U.S. Treasury - in essence, the risk premium that investors expect in compensation for interest rate risk and default risk (but not currency risk) run by investing in one particular country.

As stressed by Favero and Giavazzi (2003), a high and volatile risk premium has three main consequences for monetary policy. First, it makes the exchange rate more volatile. The mechanism works via capital flows: when the risk premium rises, capital stops flowing in and the exchange rate depreciates in real terms, causing a surplus in the trade balance that outweighs the weakening in the capital account position. Exchange rate volatility complicates the conduct of monetary policy and the attainment of price stability, as discussed above. Moreover, since part of the Nigerian public debt is denominated in foreign currency, changes

${ }^{17}$ The EMBI+ indices are an extension of EMBI (Emerging Markets Bond Index) and track all of the external currency-denominated debt markets of the emerging markets. The EMBI tracks the markets of Brady bonds and other similar sovereign restructured bonds. 
in the exchange rate trigger fluctuations in the ratio of public debt to GDP. Second, changes in the risk premium affect short-term policy rates via inflation expectations. Changes in the EMBI can in fact affect expectations of inflation directly, or indirectly via EMBI's effect on the exchange rate. Inflation expectations are the intermediate target of policy when the central bank aims at stabilizing long-run inflation but the lags of transmission are long and variable. So changes in the EMBI, by swaying inflation expectations, shift the guidepost of policy in the shorter run and thereby affect monetary actions. Third, changes in the risk premium influence the return on long-term securities either by influencing interest rate risk, term premia, and default risks - all of which feed onto that return — or via the effect that changes in the short-term interest rate have on expectations about that return.

Table 4 lists the average and volatility (both expressed in basis points) of the EMBI+ spread based on monthly averages for Brazil, Colombia, Mexico, Peru, Poland, South Korea, and Nigeria over the period January 1997 to December 2002. ${ }^{18}$ Over this period, Nigeria displays — by far - the highest spread on average around 670 basis points higher than that of Brazil, which is the second highest in the group. All spreads are quite volatile, with standard deviations always higher than 118 basis points apart from the case of Poland. Nigeria's spread is also rather volatile.

Table 4. Emerging Markets Bond Index+ (EMBI+)

(Based on monthly averages 1997:01-2002:12)

\begin{tabular}{lccc}
\hline Country & Average & Standard Deviation & Coefficient of Variation \\
\hline & & & \\
Brazil & 879.35 & 389.07 & 0.44 \\
Colombia & 651.18 & 118.48 & 0.18 \\
Mexico & 443.40 & 150.03 & 0.34 \\
Nigeria & 1634.52 & 129.83 & 0.08 \\
Peru & 601.75 & 120.64 & 0.20 \\
Poland & 233.03 & 38.17 & 0.16 \\
South Korea & 236.37 & 145.39 & 0.62
\end{tabular}

Note: Exact samples are Colombia: 1999:05-2002:12; Peru: 1998:01-2002:12; Poland: 1998:01-2002:12; South Korea: 1998:05-2002:12. For Brazil and Mexico, the data for 1997 refer to EMBI, not EMBI+. Source: Author's calculation based on J.P. Morgan data.

One conclusion from Table 4 is that markets perceive the riskiness of the Nigerian government debt to be high and, in fact, higher than that of other emerging market economies debt. This indicates that —at least from the markets' point of view — the fiscal stance in Nigeria is extremely vulnerable, a consequence, most probably of the there observed volatility in Nigerian fiscal revenues and expenditures, of the absence of a financial buffer to cushion against a decline in oil prices, of the weak tax system and of the poor quality and effectiveness of public spending programs. In these circumstances, it is reasonable for investors to expect that the government may default on its debt or that it may resort to

${ }^{18}$ The EMBI+ (or the EMBI) is not available for Chile and South Africa. 
finance a significant part of its expenditure by printing money. Put differently, the EMBI+ spread reveals that it is felt that in Nigeria the exigencies of the budget can too easily take precedence over the control of inflation: the central bank is 'fiscally dominated.'

From a monetary policy perspective, this confirms the view that in Nigeria there is little room for actively setting monetary conditions, whatever the regime chosen. In addition, since the EMBI+ spread interacts with the exchange rate and domestic interest rates, and affects the extent of fiscal dominance at each point in time, for Nigeria it is reasonable to assume that successfully embarking on active monetary policy aimed at price stability may be in any case hard. It is equally plausible to assume that this may be harder in Nigeria than in other parts of the emerging market world currently engaged in inflation targeting where risk premia are lower, or less volatile, or both.

\section{A Way Ahead for Monetary Policy in Nigeria?}

Results from the previous section suggest that Nigeria does not enjoy ideal conditions for adopting a monetary policy regime aimed primarily at stabilizing prices under a freely floating exchange rate.

There are a number of reasons for this. Nigeria faces a very volatile macroeconomic environment and a more acute inflation-output trade-off than other emerging market economies which have embraced price stabilization programs and thereby abandoned their exchange rate anchors. Moreover, Nigeria has an intense exchange of goods and services with the rest of the world, and one that is stronger than other emerging market economies, thanks to its mainly oil-exporting-oriented economy. This can make it particularly exposed to price and quantity-type external shocks, which renders price stabilization all the more complicated. Analysis on variance error decomposition reveals that, although Nigerian CPI inflation is not that sensitive to commodity price shocks - notably shocks to the price of oilchanges in the Nigerian exchange rate are passed through sizably and significantly onto Nigerian consumer prices, again in a more dramatic way than in other emerging market economies countries. This creates problems for the conduct of a monetary policy aimed at price stability because optimal policy responding to exchange rate shocks depends on the source and duration of the shock, which are typically unknown and hard to decipher in an unstable macroeconomic environment.

Finally, judging by the risk premium on dollar-denominated Nigerian sovereign debt relative to same risk premia of other emerging market economies' debt, the Nigerian fiscal policy appears extremely vulnerable — a reflection of the fact that the Nigerian central bank is fiscally dominated in the sense of Masson and others (1997). The size and volatility of the Nigerian risk premium on government debt means that the Nigerian exchange rate, as well as short- and long-term rates, may vary endogenously with the debt-to-GDP ratio (which in turn depends on the premium itself). Both facts indicate that it is hard, if not impossible, in the current circumstances to talk about active monetary policy in Nigeria of whatever kind. As emphasized in Favero and Giavazzi (2003), large and variable term premia and credit risks reinforce the possibility that a vicious circle might arise, making the fiscal constraint on monetary policy more stringent. In particular, inflation stabilization may fail if policy is nonRicardian: yet another bad omen for switching to an explicit price stabilization strategy. 
Given these initial conditions, it is reasonable to expect that aiming for and adopting a stable prices/free float regime in the long run in Nigeria may not lead to successful outcomes. In addition to not achieving the intended aims, it could be argued that pursuing unsuccessfully a price stabilization regime may harm the credibility of the central bank going forward. Sims (2003), for instance, emphasized that when conditions are such that an inflation targeting commitment has a high probability of proving unsustainable-like when the necessary fiscal backup to monetary policy is not available-embracing nevertheless explicit inflation targets can be unproductive or lead to an initial success that only amplifies a later failure.

So how does the alternative corner solution, namely, unilateral dollarization/euroization, score? And is this likely to enhance the credibility of the Nigerian central bank relative to a stable prices/free float regime? Figure 4 plots the (log of the) Nigerian nominal effective exchange rate (LXRATE) from 1990 Q1 till 2002 Q4. As the figure indicates, the Nigerian currency has been virtually in "free fall" during the past 10 years, with a depreciation over this period of around 90 percent in nominal terms. In these circumstances, arbitrary interventions to limit the variability of the exchange rate in the absence of a credible commitment to a transparent, coherent, and defensible monetary strategy is unlikely to inspire confidence or build central bank credibility. Starker forms of exchange rate fixing, like unilateral dollarization/euroization whereby the central bank explicitly commits to prevent the exchange rate from moving from a fixed parity with the U.S. dollar/euro, are in principle possible ${ }^{19}$ but may have even more undesired consequences.

First, fixed exchange rates, especially in the form of dollarization/euroization, sacrifice seigniorage revenues, which may be a relatively important source of government income in a country with a weak tax system like Nigeria. ${ }^{20}$

Second, unilateral dollarization/euroization complicates relative price adjustments. Imagine, for example, a persistent decline in the price of oil, leading to a fall in the Nigerian real exchange rate. Under flexible exchange rates, the nominal value of the naira vis-à-vis other currency can depreciate to deliver the required real exchange rate adjustment. However, under unilateral dollarization/euroization, domestic prices have to fall instead, requiring costly downward wage and price adjustments and consequent output losses which would in turn worsen permanently public finances. At the same time, unilateral dollarization/euroization limits policy flexibility giving the country resorting to it no voice in the monetary policy it runs. Put bluntly, unilateral dollarization/euroization is tantamount to handing over monetary policy to a foreign country, the one to which the domestic currency is fixed against. There is clearly no guarantee that the foreign country monetary policy follows

${ }^{19}$ At US\$6 billion, average foreign exchange reserves in Nigeria over the past five years exceed the average, outstanding stock of narrow money in circulation. This implies that Nigeria would meet the minimum reserve criteria to set up a currency board, for example.

${ }^{20}$ Partial losses of seigniorage revenue are, however, also a feature of successful monetary policies within stable prices/free float regimes. 
a course suitable to smooth aggregate demand in the exchange-rate-fixing country or that this will deliver the amount of price stability appropriate for that country. ${ }^{21}$

Figure 4. Nigeria's Nominal Effective Exchange Rate (in logs): 1990 Q1-2002 Q4

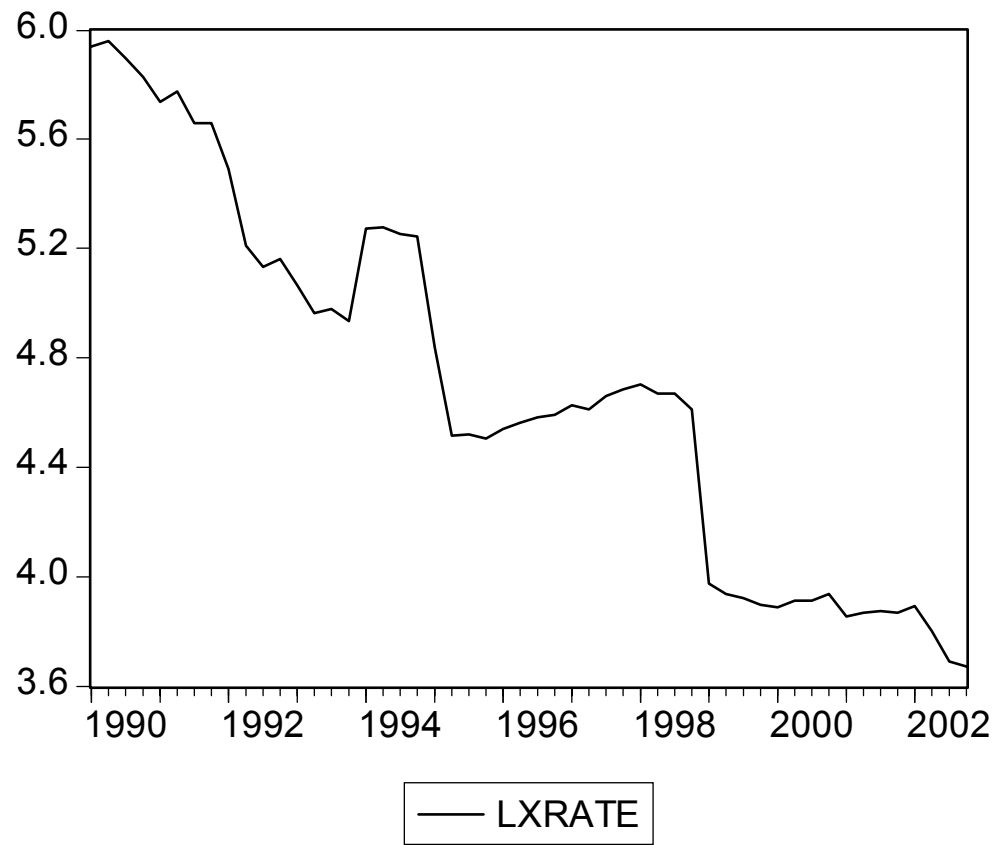

Third, as we learn from past and recent currency crisis, it can subject the central bank and its reserves to speculative attacks. Given the nature and size of short-term international capital flows, even a country well endowed with foreign reserves can in almost no time start hemorrhaging hard currency in defense of an announced parity, and therefore be forced to either devalue or abandon the exchange rate commitment altogether.

Fourth, official dollarization/euroization—like other policies involving currency pegs - is equivalent to providing implicit insurance against currency risk, which discourages private purchases of currency hedges. With unhedged liabilities, the implications of a forced devaluation can be dramatic and lead to financial contagion, especially in emerging markets

${ }^{21}$ The crisis of the Exchange Rate Mechanism in the early 1990s is a clear example in this respect: the Bundesbank high interest rate policy aimed at reining in the German inflationary demand shock that followed the German re-unification was inconsistent with demand conditions in the United Kingdom and Italy, and eventually led to costly speculative attacks against the pound and the lira, and to a subsequent abandonment of the parities by both countries. 
where most of the obligations of banks, corporations, and governments - their foreign obligations in particular - are denominated in foreign currency, while large shares of their revenues are domestic-currency denominated. This could be particularly problematic for a country like Nigeria, where the risk premium on foreign-currency-denominated government debt affecting the market exchange rate is so sizable and volatile.

In short, it seems as if, in the case of Nigeria, none of the corner solutions available is particularly attractive - an unsurprising impasse in a world in which markets are international but governments are national. However, given that: (a) it poses no immediate threats to the financial system; (b) credibility in Nigeria is yet to be built given the poor past inflation and exchange rate performance (a sort of "one cannot fall from the floor" argument); and that (c) it is at least a form of active monetary policy in which the country remains in charge of financial stability, the stable prices/free float solution still looks like the less dangerous solution: a practical second best. There are then three further reasons why a stable prices/free float solution may be the most promising for Nigeria.

- If the pursuit of stable prices comes in the form of a fully-fledged inflation targeting regime as currently exists in Britain, Chile, or South Africa, it can raise Nigerian institutional commitment to price stability, while making alignment of fiscal policy with monetary policy more likely — as it may become harder for the government to push the central bank to pursue short-run expansionary policies that are inconsistent with the price stability goal.

- $\quad$ Second, de facto, a stable prices/free float solution seems the only solution consistent with Nigeria's auspices and role in the establishment of a West African Monetary Zone (WAMZ), and with plans of the Economic Community of West African States (ECOWAS) to achieve a single currency by $2005 .^{22}$

These plans come as a response to a political commitment expressed in 1999 by ECOWASs' heads of state to accelerate the pace of regional economic integration. WAMZ would constitute a secondary monetary union in West Africa (in addition to the existing West African Economic and Monetary Union, or WAEMU, which is based on the CFA Franc) and would include six member countries, i.e., ECOWASs' non-WAEMU members. ${ }^{23}$ Nigeria, together with the other five signatory countries, has committed itself to four primary and six secondary convergence criteria, which are deemed necessary to be eligible to take part in WAMZ. Among them is the reduction of inflation below 5 percent by member countries, the reduction of budget

${ }^{22}$ ECOWAS has prescribed four primary and six secondary convergence criteria to assess whether countries are eligible to take part in WAMZ. Among them is the reduction of inflation below 5 percent by member countries.

${ }^{23}$ These include The Gambia, Ghana, Guinea, Liberia, Nigeria, and Sierra Leone. WAEMU countries instead include Benin, Burkina Faso, Côte d'Ivoire, Guinea-Bissau, Mali, Niger, Senegal, and Togo. 
deficits - excluding grants - to 4 percent of GDP, and a limit for central bank refinancing of budget deficits of 10 percent of the previous year's tax revenues (see Masson and Pattillo, 2001). So according to its WAMZ plans, Nigeria can no longer afford protracted departures from a long-run stable price level and appears to need a strategy that ensures against this possibility.

- $\quad$ Third, the stable prices/free float solution does not rule out a priori occasional interventions to stabilize the level of the exchange rate, something that may be desirable in a country like Nigeria which is extremely open and, thus, subject to large external shocks. ${ }^{24}$ In fact, there is no reason why Nigeria could not adopt a target on inflation in conjunction with a crawling band for the exchange rate, as done, for example, by Chile and Israel during their disinflations. In both these countries this strategy paid out by lowering inflation and stabilizing the exchange rates - the key to success being that the inflation target always took priority over the exchange rate one when conflict arose.

\section{Opting For Price Stability in Nigeria}

\section{A. Which Stable Prices/Free Float Regime for Nigeria?}

Today's most popular form of stable prices/free float regime is inflation targeting (see Mishkin and Schmidt-Hebbel, 2001). It has been used with success by numerous central banks in industrialized countries since the early 1990s. It also seems to have become the leading candidate for monetary policy in emerging market economies that have decided not to fix the exchange rate "permanently" through, for example, a currency board or official unilateral dollarization/euroization. Price level targeting, a stricter objective than inflation targeting whereby the central bank stabilizes the level of general prices around a constant as opposed to a growth rate, has in fact never been used in practice, other than in Sweden in the 1930s (see Batini and Yates, 2003). At root, inflation targeting entails announcing a target for inflation (typically consumer price inflation or some "core" definition of CPI that strips out highly volatile components like food and energy). The central bank task is to alter monetary conditions to keep inflation "close" to the target. Since current inflation is usually predetermined by existing price contracts, the central bank often aims at stabilizing expected inflation — which it can instead impact almost instantaneously — around the target. To do so it needs to form some view about future inflation. It follows that, typically, the forecasting of inflation—either explicit or implicit—plays a critical role in the conduct of monetary policy under inflation targeting.

Obviously, inflation targeting and flexible exchange rates are not synonymous since the latter can coexist with a number of alternatives to inflation targeting or even exist in the absence of a coherent monetary policy strategy. However, inflation targeting requires the central bank to be free to change monetary conditions in order to pursue the target. This

${ }^{24}$ If exchange rate interventions become too frequent, however, an inflation-targeting regime and a hard peg regime become virtually indistinguishable. See Eichengreen (2002). 
implies that inflation targeting cannot coexist with fixed exchange rates - or indeed with hard pegs - because in that case the policy instruments cannot be used for domestic purposes. So inflation targeting is normally accompanied by flexible exchange rates, even if the degree of flexibility may vary according to each country's distaste for exchange rate volatility (see Calvo and Reinhart, 2000).

An inflation-targeting regime can take various forms. These range from simply making a public announcement of numerical targets for inflation for the year(s) ahead to a full-fledged monetary policy operating strategy. Mishkin (2000) defines full-fledged inflation targeting as a strategy with five elements:

“(i) [t] he public announcement of medium-term numerical targets for inflation; (ii) an institutional commitment to price stability, to which other goals are subordinated; (iii) an information inclusive strategy in which many variables, and not just monetary aggregates or the exchange rate, are used for deciding the setting of policy instruments; (iv) increased transparency of the monetary policy strategy through communication with the public and the markets about the plans, objectives, and decisions of the monetary authorities; and

(v) increased accountability of the central bank for attaining its inflation objectives" (Mishkin, 2000: 1-2).

As Mishkin (2000) points out, inflation targeting has many advantages as a mediumterm strategy for monetary policy. For these to accrue, all elements of the full-fledged inflation targeting strategy are necessary. Notably, announcing a specific target for inflation and institutionalizing the commitment to price stability enhance the credibility of the strategy and its objectives. The institutional commitment is also important on two other grounds.

First, it helps anchor expectations by elevating price stability to the status of primary goal for the central bank. This clarifies that all other goals — stated or unstated-are less important, although these can be pursued as secondary objectives in a lexicographic sense. So in a flexible exchange rate regime with a target on inflation, for example, central bank intervention in support of the exchange rate should be limited to smooth the effects on temporary shocks on inflation and should be sterilized, isolating monetary policy from the effect of the intervention. ${ }^{25}$ Moreover, over time, sales of foreign exchange should be balanced by purchases so that the net reserves stay the same.

Second, the institutional commitment involves a legislative framework whereby the central bank is operationally independent in the pursuit of its mandate, that is, it is granted complete control over the setting of monetary instruments and is insulated by political

${ }^{25}$ However, deciding when to intervene is difficult because it requires the central bank to know the nature and the duration of the shock that has caused the exchange rate to change in the first place. 
interferences. ${ }^{26}$ Finally, use of many indicators in the conduct of monetary policy is important: expected inflation ought to embody all information contained within the myriad variables that affect the future path of inflation. This has the benefit that policy is not myopically focused on one or two indicators alone, as for example under money targeting or exchange rate targeting, but is based on a rich information set that is less likely to be collectively distorted by idiosyncratic shocks.

In these terms, a full-fledged inflation targeting strategy seems a good long-run strategy for Nigeria, and a better one than a milder strategic version of inflation targeting. The institutional commitment to price stability would in fact clarify the mandate of the CBN, which at present contains too many (incompatible) objectives. Since the commitment would have to come from the government, it would raise the responsibility of the government in attaining stable prices. It could then make it harder for the government to conduct fiscal policies that are plainly incompatible with the announced monetary policy objective.

\section{B. A Target for Stable Prices in Nigeria}

What would be the appropriate long-run target for price stability in Nigeria? An operating definition of price stability that is now universally accepted has been offered by Alan Greenspan, Chairman of the Federal Reserve's Open Market Committee: "[P]rice stability obtains when economic agents no longer take account of the prospective change in the general price level in their economic decision making" (Greenspan, Testimony to U.S. Congress, 1996).

In general, the particular rate at which economics agents start disregarding prospective inflation is believed to correspond to an annual rate of inflation between 0 and 3 percent, a range of rates typically deemed adequate as a numerical long-run inflation goal for both developed and emerging market economies (see Mishkin and Schmidt-Hebbel, 2001).

The lowest bound on this range, namely, a 0 percent target rate for inflation, has been advocated by Feldstein (1997) and Poole (1999) on the basis that this implies a stable price level - as opposed to a stable rate of growth of prices - and so minimizes the uncertainty surrounding the plans of economic agents. Feldstein (1997) and Poole (1999) also claim that zero percent has a psychological appeal because it can be perceived as a "magic" and "perfect" number. On the other hand, other researchers including Akerlof, Dickens, and Perry (1996) and Groshen and Schweitzer (1999) argue against a zero percent inflation target on the basis that a little positive inflation can help labor markets to adjust when nominal wages are rigid downwards. A further argument against setting the inflation target to exactly zero percent comes from Mishkin $(1991,1997)$, who claims that low but non-zero target rates for inflation make it less likely that the economy will experience episodes of deflation.

26 "Operational" or "instrument" independence, does not involve "goal" independence. Ideally, the latter should, in fact, rest with the government on political acceptability grounds (see Debelle and Fischer, 1994). 
Higher numerical values for long-run inflation targets, of the order of 3 to 4 percent, have been on occasion advocated for emerging market economies on the basis of HarrodBalassa-Samuelson effects considerations. Errors or biases inherent in the calculation of the consumer price index, which can be particularly severe due to data deficiencies and/or inconsistencies in developing countries, are yet another reason for suggesting higher long-run inflation targets in these countries (Škreb, 1998:181).

Typically, for an emerging market country — or indeed any other country - mediumto long-run goals greater than 3 or 4 percent are never advocated. ${ }^{27}$ This is for at least three reasons. First, empirical evidence shows that inflation beyond a certain low level can hurt growth. Assuming a non-linear relationship between inflation and growth and looking at a sample of 51 emerging market economies, Burdekin and others (2000) for instance find that inflation in these countries has a negative effect on growth for rates above 3 percent. Surprisingly, this threshold is lower than what they find for developed countries ( 8 percent $).{ }^{28}$ This is also true when assuming linear relationships, for both developed and developing countries, but then the power of the test is unlikely to help discriminate between different long-run goals which are less than 10 percent (see, for instance, Bruno and Easterly, 1995; and Brook, Karagedikli, and Scrimgeour, 2002).

Second, the conventional wisdom is that long-run target rates above 4 percent can too easily lead to a decline in central bank credibility and instability in inflation expectations, especially in developing countries where the reputation of the monetary authorities is usually fragile because the government typically follows fiscal surplus policies. This may well cause an upward creep in inflation, making the inflation target not sustainable in the long run (see, among others, Morandé, 2000, and Mishkin and Schmidt-Hebbel, 2001). Finally, given the well-known relationship between the level and the variance of inflation, target rates higher than 3 or 4 percent have the negative implication of bringing about greater inflation volatility. This in itself may defy one of the most important motives for pursuing price stability in any country, namely, minimizing the variance of inflation to foster the predictability and confidence that underlie sound economic planning and growth.

In sum, to date the economic profession agrees on what price stability means - a rate of inflation that is sufficiently low that households and businesses do not have to take it into account in making everyday decisions. There is perhaps less of a consensus on the exact number to use for an inflation target (other than the widely shared view that this should certainly range between a minimum just above 0 percent and a maximum of 3 or 4 percent for both developed and emerging market countries) than on grounds of sustainability and long-run growth.

27 They can, however, be advocated as interim targets for short periods of time - that is, as transition targets to long-run goals.

${ }^{28}$ This difference in results is probably due to the fact that the relationship between inflation and growth is more linear in developed than in developing countries. 
Mishkin and Schmidt-Hebbel (2001) indicate that, in this spirit, all inflation targeting countries in their world sample have chosen "long-run inflation goals slightly above zero, with the midpoints of the long-run target ranges lying between 1 and 3 percent" (Mishkin and Schmidt-Hebbel, 2001: 30). A similar long-run inflation target would, therefore, probably be appropriate for Nigeria as well. Given then that inflation in Nigeria is presently double-digit, Nigeria may additionally need to announce interim inflation targets to be achieved in the shorter to medium run. This is the practice followed by, for example, Brazil and Chile, which committed to increasingly lower inflation over a specific policy horizon in order to attain the long-run target gradually and at the minimum output gap variability cost. Appropriate interim inflation targets for Nigeria will depend on the degree of central bank credibility and on the Nigerian inflation-output trade-off, and so their specification needs to be studied carefully_an issue not examined here.

\section{Operationalizing Price Stability in Nigeria via a Simple Plan}

In the past, policymakers have often failed to attain price stability. Examples of double-digit inflation and even hyperinflations - episodes of explosive upward inflation dynamics, usually followed by dramatic recessions and unprecedented rates of unemployment — are plenty both in the developed and the developing world (see Blejer and others, 1999). This is also the case of Nigeria that, in the period going from the early 1980s to the second half of the 1990s, has experienced average annual inflation rates of around 30 percent. Figure 1, plotting year-on-year changes in the Nigerian CPI (D4CPI), the output gap (GAPNIG), and the nominal discount rate (DR), emphasizes this point. In line with the conventional wisdom that there is no relationship between inflation and real variables in the long run, the figure shows that periods of high inflation did not translate into periods of higher output in Nigeria, even allowing for time lags.

One way to implement a price-stability-oriented regime consists in specifying a simple "plan" or "formula" for the policymaker, something which states where nominal interest rates should be for inflation to stabilize near its low, long-run target rate. With an explicit inflation target, a good rule will be one which ensures that fluctuations of actual inflation from its long-run target will be small. In 1993, John B. Taylor published a short paper showing how the secret of success in monetary policy as accrued by the Federal Reserve after the onset of the Volcker-Greenspan era could be described precisely by such a simple formula for the policy instrument - the short-term nominal interest rate. This formula takes the name of its author, and became known worldwide as the "Taylor rule." The number of papers showing the strengths of Taylor rules when applied to both developed and developing countries is vast. Taylor (2000b) himself, for instance, showed that the Taylor rule can be at the heart of monetary policy success also in emerging market economies with flexible exchange rates, like Nigeria. In Taylor's words:

"For those emerging market economies that do not choose a policy of "permanently" fixing the exchange rate_perhaps through a currency board or dollarization, the only sound monetary policy is one based on the trinity of a flexible exchange rate, an inflation target, and a monetary policy rule" (Taylor, 2000b: 1, original emphasis). 
The Taylor rule specifies that the nominal interest rate should be set at a level equal to the long-run equilibrium interest rate plus the inflation rate. The long-run equilibrium real interest rate should be close to the long-run real potential growth rate of the economy. The rule then adds two adjustments related to the extent to which inflation differs from a target inflation rate (the inflation gap) and the log of actual output minus the log of potential output (viz, the percentage difference between actual and potential output, i.e. the output gap). In pseudo-mathematical form:

Nominal interest rate $=a+b \times($ actual inflation - inflation target $)$

$+c \times$ (percentage difference between real and potential output)

where $a$ is the nominal equilibrium interest rate (that is the long-run equilibrium real interest rate plus the steady state inflation rate. This is usually proxied with the current or lagged inflation rate), and $b$ and $c$ are positive parameters.

There are three important principles to be borne in mind when using this rule. First, the coefficient $b$, i.e., the one governing the response of nominal interest rates to inflation, must be positive. This ensures that the real interest rate (nominal interest rate minus inflation) moves upwards (or downwards, depending on the circumstances), which is a necessary condition to trigger monetary transmission and, thus, affect inflation in the desired way - the so-called "Taylor principle." Second, the output of the rule must not be followed mechanistically by the central bank. Discretion should be applied as suggested by Taylor (1993) himself, with typical examples being one-off shocks to the price level (like an oil shock) when these are believed to have no impact on inflation expectations. Third, a policy rule is to be used, and expected by the public to be used, for many periods into the future, so that the public learns to expect the "correct" response by the central bank to inflationary shocks and thereby learns to expect low inflation. These "low inflation expectations" are factored in workers' and firms' choices, making expectations self-fulfilling.

In essence, monetary policy rules like the Taylor rule simply state where nominal interest rates should be for inflation to stabilize near its target rate. The Taylor rule has various strengths. First, it attempts to provide directly some indication of the appropriate level of nominal rates, given the current conjuncture, which can be compared with the actual level of rates. Second, the rule is "simple" in the sense that it is relatively easy to identify what is driving any 'recommended' policy stance. Third, the rule approximates reasonably well what is generally regarded as good policy in the past. This is equally true of both developed and developing economies (Taylor, 2000b). While monetary policy is not usually run strictly according to this rule, the rule does provide a simple characterization of the "correctness" of monetary policy given the inflation and output gaps. ${ }^{29}$

${ }^{29}$ The Federal Reserve, for example, appears to have conducted monetary policy largely in accordance with the Taylor rule since 1987, at least in an intuitive way, because the rule tracks the actual Federal Reserve funds rate with an impressive 87 percent precision. The fact that macroeconomic outcomes from the Federal Reserve actions during that period were 
The main weakness of the Taylor rule has to do with measurement problems. Typically the real equilibrium interest rate (one of the components of the $a$ parameter above) and potential output are hard to measure. Also, the weights $b$ and $c$ have to be chosen carefully. Orphanides (2001) suggests that when central banks follow the Taylor rule and are uncertain about the output gap they should preferably not respond to it ( $\operatorname{set} c=0$ ). This is better than responding to an incorrectly measured gap. ${ }^{30}$ Lastly, it is possible to conduct more general sensitivity analysis on the weights $b$ and $c$.

\section{A. How Should Taylor Rules Be Used in Emerging Market Economies?}

The Taylor rule was originally designed for the United States (cf. Taylor, 1993). Researchers have shown that the original form of the rule is suitable-occasionally with minor changes - to guide policy in other developed countries (see Clarida, Galí, and Gertler, 2000; Batini, Harrison, and Millard, 2003; and Ball, 1999, among others). These rules can also be part of a monetary policy strategy in emerging market economies, as stressed by Taylor (2000b). However, specific features of emerging market economies may require modifications of the original rule advocated for more developed economies. At least six aspects of the rule would have to be reassessed if the rule were to be used in practice by an emerging market economy like Nigeria.

i. $\quad$ The feedback parameter on inflation, $\mathrm{b}$, may be set to a larger value than that commonly recommended for developed economies.

There are two reasons for this. First, emerging market economies typically enjoy less credibility than developed economies. So monetary policy may have to be more aggressive than what is typically prescribed by the rule if it were to enjoy full credibility. Second, monetary impulses work both by affecting the short-term interest rate- which in turn affects some spending and investment plans of the private sector-and via the effect that these changes have on expectations about the return on long-term securities. Yet, as Taylor (2000b) points out, emerging market economies' longer maturity markets are usually less liquid than those of developed economies. In this case, Taylor argues, expectations effects working through the term structure tend to be weak. So it may be sensible to react more strongly and more quickly to inflation deviations from target and allow the monetary transmission at the shorter end of the term structure to do more of the work. This can be achieved by increasing the value of the $b$ parameter.

good, is telling about the "correctness" of the prescriptions implicitly embedded in such a simple rule.

${ }^{30}$ A possible substitute for the output gap is a term capturing the level of last period's nominal interest rate, often referred to as a "smoothing term." Inclusion of this term makes the rule more aggressive in the long run, but ensures that policy responses are "gradual" and so avoid large interest rate changes which can be output gap destabilizing. 
ii. $\quad$ When constructing the nominal equilibrium interest rate, expected inflation-rather than lagged inflation or backward-looking averages of inflation-should be used as a proxy of steady state inflation. Absent data on this, current inflation should be used.

Emerging market economies often share a history of poor inflation performance and the public trust in the central bank desire to curb inflation is typically low to nonexistent. With little credibility and a history of high inflation, inflation expectations can ratchet up swiftly following an inflationary shock because price- and wage-setters believe that there is a high probability that the shock will be accommodated-the upshot of which will be higher actual inflation going forward. In other words, in emerging market economies inflation expectations can easily get disconnected from actual inflation so that next period's expected inflation and last period's inflation can diverge considerably, with the wedge between the two growing faster the longer the central bank waits to respond to inflationary shocks. In these circumstances it will make a difference whether the central bank uses one or the other as a proxy for expected inflation in the rule.

iii. $\quad$ The equilibrium real interest rate, also entering the construction of the nominal equilibrium interest rate, must be chosen carefully, in line with expected potential growth rate of the emerging market economy.

The way this rate is selected is crucial in determining the output of the rule because changes in the equilibrium real interest rate feed one-to-one onto the nominal shortterm policy prescriptions of the rule, and so miscalculations of the equilibrium real interest rate can easily translate into policy errors. In developed and developing countries the equilibrium real rate of interest typically oscillates between 2 percent and 6 percent, with the upper range more suitable for developing countries given the one-to-one relationship of the real interest rate and real output growth in the long run.

iv. $\quad$ The feedback on the output gap in the Taylor rule should be de-emphasized or even eliminated $(\operatorname{set} \mathrm{c}=0)$.

In emerging market economies, GDP data are often measured incorrectly because of the size of the informal sector or just due to inadequate ability to collect data or poor quality of the data. GDP data are also often only available with a lag and can be subject to large revisions. This complicates tremendously the task of estimating the output gap, the second term in the Taylor rule.

v. When computing the Taylor rule for an emerging market economy, the central bank may want to assess whether it would be appropriate to augment the rule with a feedback on the exchange rate, in line with considerations relative to the important exchange rate channel of monetary policy transmission typically active in emerging market economies. One important result in this respect is that the Taylor rule is valid in its original specification both for closed and open economies, because the full and simple optimal policy prescription is practically the same in economies with and without strong exchange rate channels of transmission (see Clarida, Galí, Gertler, 2001; and Batini, Harrison, and Millard, 2003); 
vi. In emerging market economies, it may on occasion be sensible to consider policy rules based on money rather than interest rates as instruments.

The Taylor rule assumes that the interest rate is the instrument of monetary policy. As stressed by Poole (1970), the benefits of an interest rate policy instrument compared with a money-base or other monetary aggregate instrument depend on the composition of shocks hitting the economy at any point in time. If velocity shocks dominate, having an interest rate instrument is superior to having a money-base instrument. If, however, shocks to investment and/or exports dominate, or if it is difficult to measure reliably the actual and equilibrium real interest rate, as is often the case in emerging market economies, then the reverse is true.

\section{The Historical TAYlor-Rule-Implied PATH FOR Nigeria}

\section{A. Taylor Rules for Nigeria}

Figure 5 plots the "output" of the Taylor rule for Nigeria when (i) various combinations are used of parameters $a$ (values vary between 2 and 5 percent for the real equilibrium interest rate), ${ }^{31} b$ (varies between 0 and 1 ), and $c$ (varies between 0 and 1 , where values closer to zero minimize the effect of a potentially wrongly measured output gap); (ii) the target for inflation is chosen as the midpoint of the implicit target range within two subperiods (dashed line). ${ }^{32}$ Or, alternatively, the target is chosen as the sample mean of annual CPI inflation between 1991 and 1996 (45.65 percent) and a 4 percent hypothetical annual inflation target thereafter (all other Taylor rule lines in the figure). This value seems consistent with findings on the optimal long-run rate of inflation in developing countries like Nigeria (see Section II B); (iii) potential output is computed using a standard filtering procedure. The figure also plots the actual annualized Minimum Rediscount Rate (MRR) and inflation levels at selected points in time. Obviously there are numerous permutations and combinations of possible values and this is only a sample of values. For policy purposes the central bank has to give input into the parameter values to be used in the monetary policy rules.

Two main points emerge from the figure.

First, from 1991 to 1996, policy seems to have been "exceptionally loose" relative to what the rule implied. Deviations of the actual MRR from the Taylor-implied rate at each point in time over this period are as large as 9000 basis points (i.e., a difference of

${ }^{31}$ A value of 4-5 percent for the real equilibrium interest rate seems appropriate for a developing, middle-income country with trend annual real GDP growth between 4 and 5 percent, such as Nigeria.

32 The implicit annual target for inflation in Nigeria is proxied with the sample mean of CPI year-on-year inflation over two main subperiods: 1991-1996 and 1997-2001. Annual inflation over the first subperiod was equal to about 46 percent, and fell to an average around 10 percent over the second subperiod. 
90 percentage points). This followed the fact that in the 1990s (and 1980s) monetary policy (and interest rate setting) was often constrained by fiscal surprise, particularly monetary financing of large fiscal deficits which averaged 5.6 percent of GDP annually over that period. In turn, this led to undue monetary expansions and, thus, a lower than adequate level of nominal interest rates. In the spirit of what was discussed in the previous sections, this may explain why inflation has been rising sharply or stayed high after shocks during those periods.

Second, monetary policy in Nigeria seems to have been about right post-1996, till about the end of 1999, according to the Taylor rule under the stationary inflation goal of 4 percent. (If anything, policy appears to have been briefly on the tight side from $1998 \mathrm{H} 2$ to 1999 H2.) This followed the moderation of fiscal surprises in that period and, more generally, the greater autonomy of the $\mathrm{CBN}$ in the conduct of monetary policy that followed the introduction of the new CBN (Amendment) Decree No. 37 and BOFI (Amendment) Decree No. 38 in late 1998 (see Ojo, 1999). More recently, however, monetary conditions seem again "too loose" according to the rule - a consequence of renewed largesse in fiscal deficits and of low administratively-set interest rate ceilings. ${ }^{33}$

Figure 5. Nigeria Minimum Rediscount Rate (MRR) vs. Taylor-Rules-Implied Rates

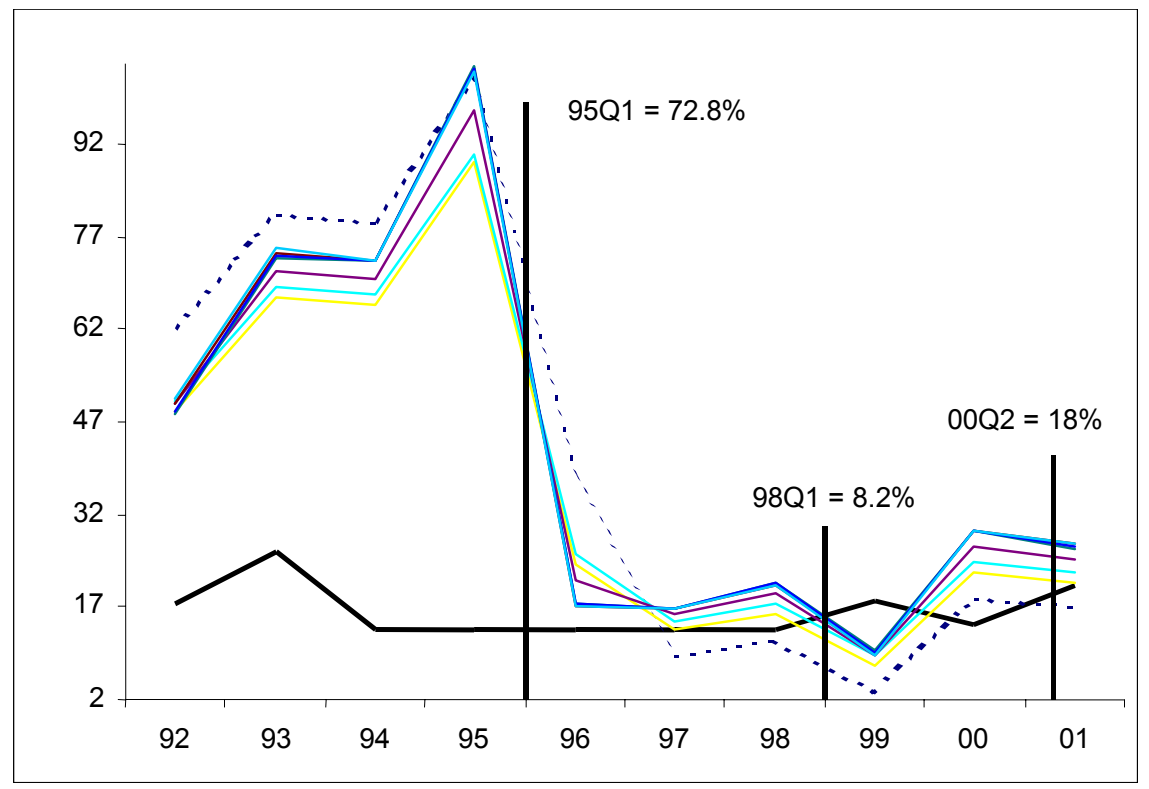

In general, results here seem to suggest that if the $\mathrm{CBN}$ had been granted independence in setting monetary conditions and had followed a Taylor rule, monetary conditions might have been tighter in the past twenty years and, hence, inflation might have been lower and less volatile than what has been observed in the past. Thus, one corollary of these findings is that to maintain the late 1990s inflation record and possibly achieve sustainable one-digit inflation rates in Nigeria, it may be necessary to have greater

${ }^{33}$ See IMF (2003): 8. 
institutional CBN autonomy accompanied by greater fiscal prudence than those seen in the $1980 \mathrm{~s}$ and $1990 \mathrm{~s}^{34}$

\section{B. Taylor Rules for Other Emerging Market Economies}

Estimates of Taylor rules for emerging market economies, like Brazil (Carneiro and Duarte, 2001) and South Africa (Aron and Muellbauer, 2002) give mixed results, but generally fit the data poorly. The authors conclude that this suggests that historical monetary policy regimes in these countries followed multiple-targets approaches to stabilization.

Figures 6-8 graph the Taylor-implied interest rate path versus the actual short-term nominal interest rate path for three other developed and middle-income countries, namely, for Brazil, Chile, and South Africa. ${ }^{35}$ The figures also indicate average inflation levels over various periods. All these countries adopted explicit inflation targets in recent years, and so it is interesting to see whether this shift in regime had implications for the way interest rates are now set in those countries relative to the pre-regime shift periods. In particular, Chile has introduced inflation targets in 1990, Brazil in 1999, and South Africa in 2003.

In summary, Figures 6-8 indicate that in Brazil, Chile, and South Africa, interest rates seem to have diverged more markedly from Taylor-rule-implied rates before, rather than after, the introduction of inflation targets. This suggests that inflation targeting may provide a good disciplinary framework within which to pursue price stability. On the other hand, the analysis reaffirms Taylor's intuition (Taylor, 2000b) that the introduction of inflation targets does not guarantee per se that policy is set adequately.

As discussed before, the preference for low inflation must be accompanied by a response to inflationary pressures such that, at each point in time, the short-term nominal interest rate moves by more than one-to-one with changes in the general price level expected to prevail next period - a condition that is even more stringent when the monetary authority lacks full credibility. As Figures 7 and 8 indicate, the interest rate has been below the rule-implied path for prolonged periods of time both in Brazil and in South Africa, mainly in violation of the Taylor principle, as short-term ex post real rates were kept constant or fell at

\footnotetext{
${ }^{34}$ Fiscal discipline is also one of the prerequisites for joining the WAMZ. ECOWAS has, in fact, established that in order to qualify for the WAMZ, a member country's ratio of budget deficit (excluding grants) to GDP calculated on the basis of commitment should be lower than 4 percent. In addition, the country's central bank financing of the budget deficit must stand at 10 percent of the previous year's tax revenue.

${ }^{35}$ In computing the rules, alternative calibrations of the rule parameters are used as for the case of Nigeria. Regarding the target for inflation, actual (explicit) targets were chosen for Brazil, Chile, and South Africa, when available. Before the onset of inflation targeting, the sample mean of inflation is used. This is taken to proxy the midpoint of the implicit target range.
} 
times of rising inflation. This may explain why both Brazil and South Africa have seen inflation deviate from their current targets over this period.

Figure 6. Chile: Actual Nominal Rate vs. Taylor-Rules-Implied Rates

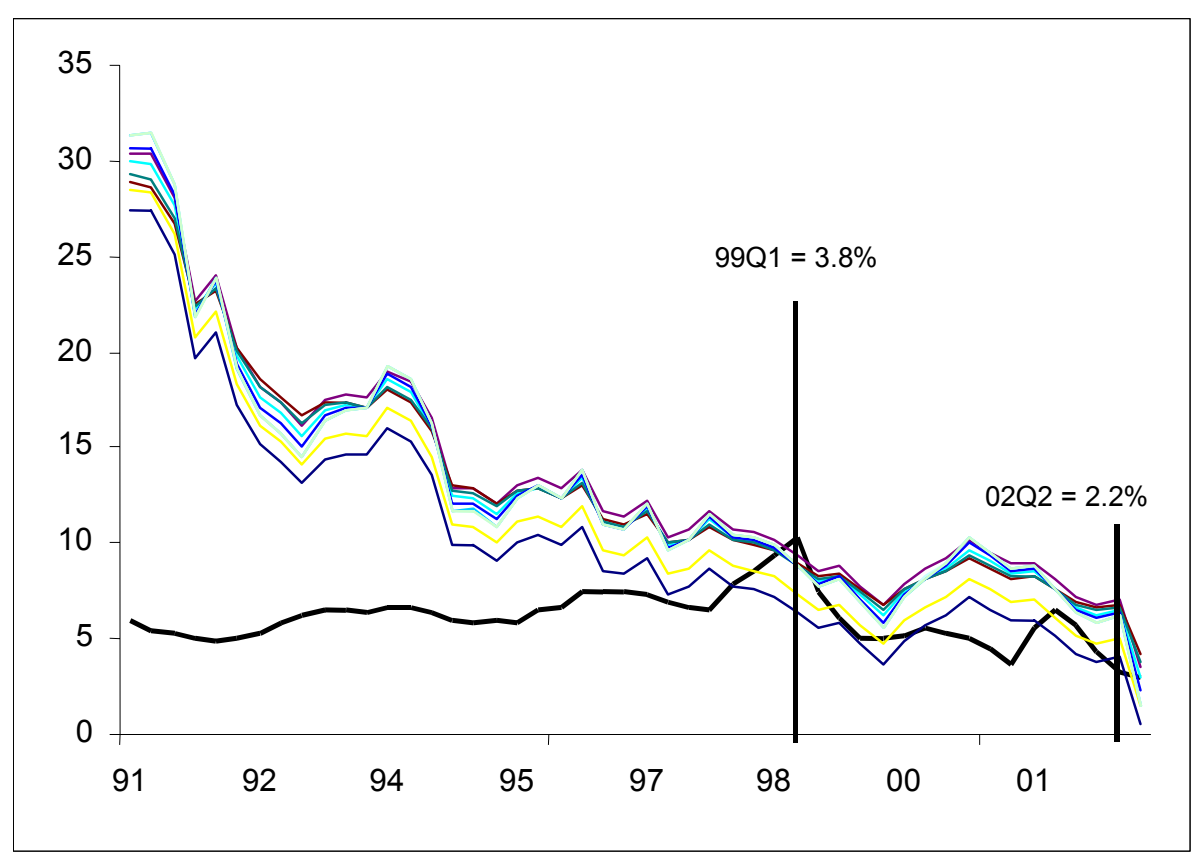

Figure 7. Brazil: Selic Rate vs. Taylor-Rules-Implied Rates

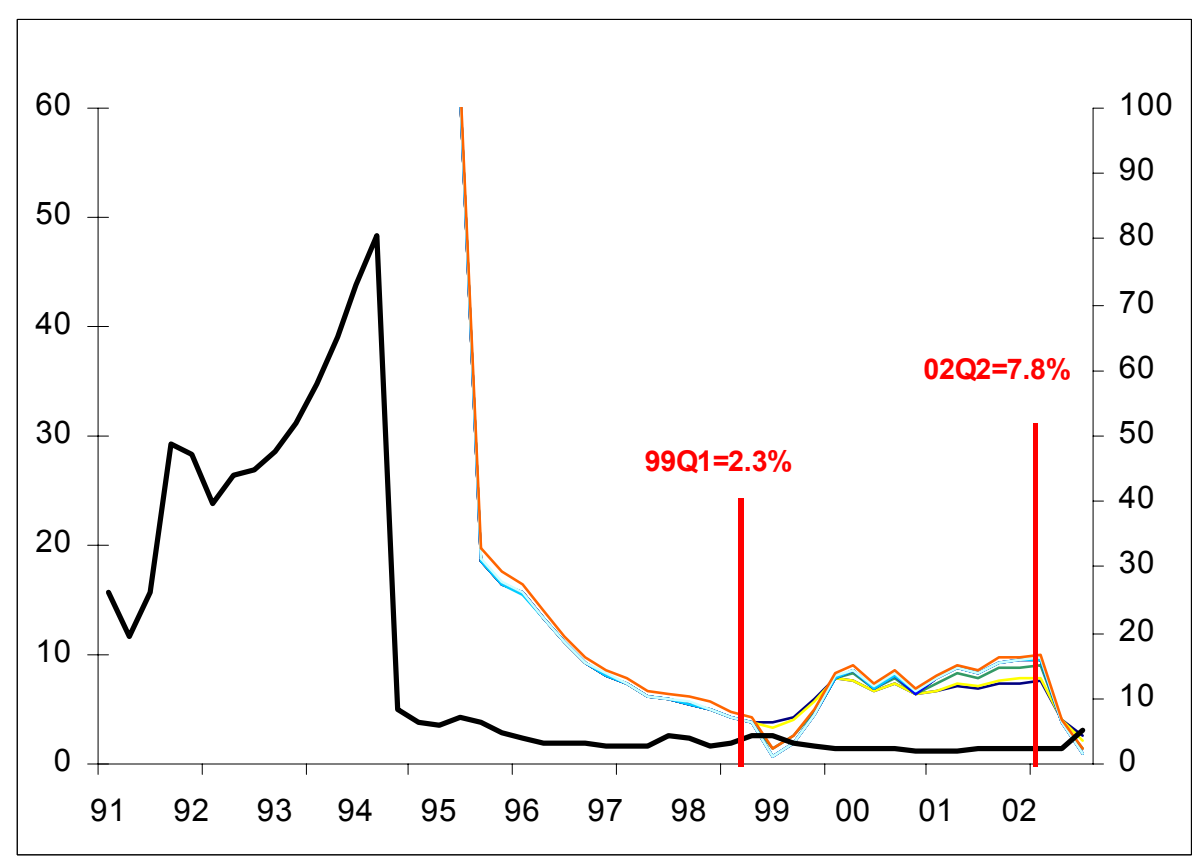


Figure 8. South Africa: Actual Nominal Rate vs. Taylor-Rules-Implied Rates

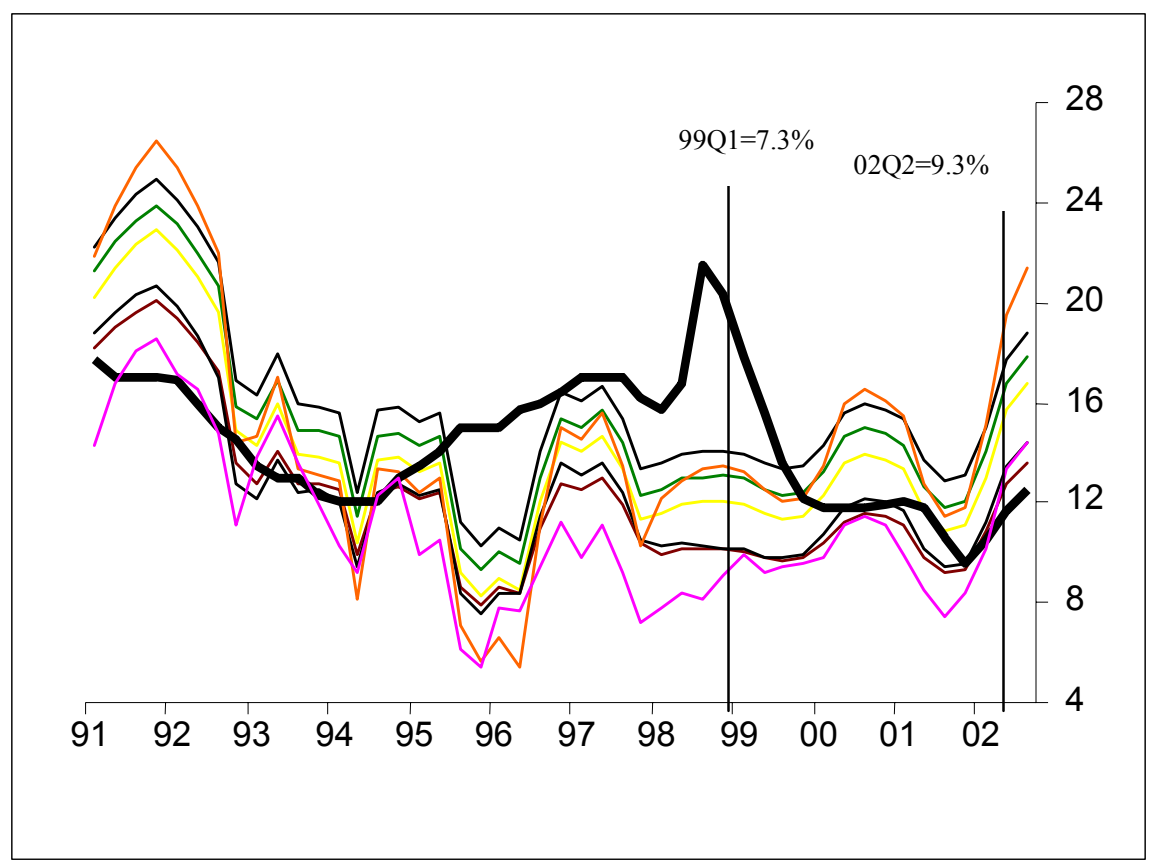

\section{CONCLUding Remarks AND Policy Implications}

This paper looked at long-run solutions for achieving and maintaining price stability in Nigeria. An analysis of Nigeria's susceptibility to external shocks reveals that price stability and a freely floating exchange rate does not look like a panacea for Nigeria's imbalanced fiscal-monetary policy mix nor for its poor inflation and exchange rate record. It also seems improbable that a stable prices/free float regime may be vastly superior to a fixed exchange rate one. However, a stable prices/free float regime may still be the best available option for Nigeria in the long run, and one in line with the existing currency regime. Partial or total dollarization/euroization - the alternative option - may not, in fact, be viable on various grounds.

The paper suggests that if, for the long run, the Nigerian government opts for the stable prices/free float "corner solution," this should be in the form of an inflation targeting regime - preferably of the "full-fledged" kind. The institutional commitment to price stability_defined by a long-run numerical target between 1 percent and 4 percent in line with other emerging market economies that target inflation, and possibly interim inflation targets, and perhaps a crawling band for the nominal effective exchange rate — would in fact clarify the mandate of the CBN and could make it harder for the government to conduct fiscal policies that are plainly incompatible with the announced monetary policy objective.

The paper also shows that a simple plan, like a Taylor rule, could provide a good benchmark for the monetary policy instrument while pursuing the inflation target, although the rule would need to be modified to suit the emerging market characteristics of Nigeria. A 
historical analysis of monetary policy in Nigeria within this framework suggests that monetary conditions might have been less accommodative and, hence, inflation in Nigeria might have been lower and less volatile than what was observed in the past had Nigeria followed prescriptions based on a rule consistent with price stability. 


\section{References}

Akerlof, George, William T. Dickens, and George L. Perry, 1996, "The Macroeconomics of Low Inflation,” Brookings Papers on Economic Activity, Vol. 1, pp. 1-59.

Aron, Janine, and John Muellbauer, 2002, "Estimating Monetary Policy Rules for South Africa," in Monetary Policy: Rules and Transmission Mechanisms, ed. by Norman Loayza and Klaus Schmidt-Hebbel, Series on Central Banking, Analysis and Economic Policies (Santiago, Chile: Central Bank of Chile).

Ball, Lawrence, 1999, "Policy Rules for Open Economies," in Monetary Policy Rules, ed. by John B. Taylor (Chicago, Illinois: University of Chicago Press).

Batini, Nicoletta, Richard Harrison, and Stephen P. Millard, 2003, "Monetary Policy Rules for an Open Economy," Journal of Economic Dynamics and Control, Vol. 27 (September), pp. 2059-94.

Batini, Nicoletta, and Jeanne Helen Gobat, 2004, "The Transition to a New Monetary Regime in Nigeria: Challenges and Goals," paper to be presented at the $3^{\text {rd Annual }}$ Conference on Rebuilding the Nigerian Financial System, organized by the Money Market Association of Nigeria, Abuja, Nigeria, May 13-15.

Batini, Nicoletta, and Anthony Yates, 2003, "Hybrid Inflation and Price-Level Targeting," Journal of Money, Credit and Banking, Vol. 35 (June), pp. 283-300.

Blejer, Mario I., Alain Ize, Alfredo Mario Leone, and Sérgio R. da C. Werlang (eds.), 1999, "Inflation Targeting in Practice: Strategic and Operational Issues and Application to Emerging Market Economies," Proceedings from an IMF seminar held in Rio de Janeiro, Brazil, May 3-5.

Brook, Anne Marie, Özer Karagedikli, and Dean Scrimgeour, 2002, “Assessing Alternative Inflation Targets: Growth Effects and Other Costs and Benefits," in Policy Targets Agreement: Reserve Bank Briefing Note and Related Papers (Wellington, New Zealand: Reserve Bank of New Zealand).

Bruno, Michael, and William Easterly, 1995, "Inflation and Long-Run Growth,” NBER Working Paper No. 5209 (Cambridge, Massachusetts: National Bureau of Economic Research).

Burdekin, Richard C.K., Arthur Denzau, Manfred W. Keil, T. Sitthiyot, and T. Willet, 2000, "When Does Inflation Hurt Growth? Different Non-Linearities for Different Economies," GSBGM Working Paper Series 12/96 (Wellington, New Zealand: Victoria University of Wellington Printers). 
Calvo, Guillermo A., and Carmen M. Reinhart, 2000, "Fear of Floating," NBER Working Paper No. 7993 (Cambridge, Massachusetts: National Bureau of Economic Research).

Carneiro, Dionísio Dias, and Duarte, P.G., 2001, "Inércia de Juros e Regras de Taylor: Explorando as Funções de Resposta a Impulso em um Modelo de Equilíbrio Geral com Parâmetros Estilizados Para o Brazil," Texto Para Discussao No. 450 (Rio de Janeiro: Pontificia Universidade Catolica de Rio de Janeiro, Departamento de Economia).

Clarida, Richard, Jordi Galí, and Mark Gertler, 2000, "Monetary Policy Rules and Macroeconomic Stability: Evidence and Some Theory," Quarterly Journal of Economics, Vol. 115 (February), pp. 147-80.

— 2001, "Optimal Monetary Policy in Closed Versus Open Economies: An Integrated Approach," NBER Working Paper No. 8604 (Cambridge, Massachusetts: National Bureau of Economic Research).

Debelle, Guy, and Stanley Fischer, 1994, "How Independent Should a Central Bank Be?” in Goals, Guidelines, and Constraints Facing Monetary Policymakers: Proceedings of a Conference held at North Falmouth, Massachusetts, June 1994, Fuhrer, J. C., Conference Series No. 38 (Boston, Massachusetts: Federal Reserve Bank of Boston).

Eichengreen, Barry J., 2002, "When to Dollarize," Journal of Money, Credit and Banking, Vol. 34 (February).

Favero, Carlo, and Francesco Giavazzi, 2003, "Targeting Inflation when Debt and Risk Premia Are High: Lessons from Brazil” (unpublished; Milano, Italy: Università Luigi Bocconi).

Feldstein, Martin, 1997, "The Costs and Benefits of Going from Low Inflation to Price Stability," in Reducing Inflation: Motivation and Strategy, ed. by Christina D. Romer and David H. Romer (Chicago, Illinois: University of Chicago Press).

Fischer, Stanley, 2001, “Exchange Rate Regimes: Is the Bipolar View Correct?” in Finance and Development, Vol. 38 (June).

Greenspan, Alan, 1996, "Opening Remarks," in Achieving Price Stability, a Symposium Sponsored by the Federal Reserve Bank of Kansas City, Jackson Hole, Wyoming, August 29-31.

Groshen, Erica L., and Mark E. Schweitzer, 1999, “Identifying Inflation's Grease and Sand Effects in the Labor Market," in Martin S. Feldstein, ed., The Costs and Benefits of Price Stability (Chicago, Illinois: University of Chicago Press). 
International Monetary Fund, 2003, "Nigeria: 2002 Article IV Consultation-Staff Report; Staff Statement; and Public Information Notice on the Executive Board Discussion," IMF Country Report 03/3 (Washington).

Katz, Menachem, 2003, "Nigeria: The Role of Fiscal Policies in Fostering Macroeconomic and Financial Stability," paper presented at the $2^{\text {nd }}$ Annual Conference on Financial Stability of the Money Market Association of Nigeria, held in Abuja, Nigeria, May $1-15$.

Khan, Mohsin S., 2003, "Current Issues in the Design and Conduct of Monetary Policy," IMF Working Paper 03/56 (Washington: International Monetary Fund).

Kumhof, Michael, 2000, “Inflation Targeting Under Imperfect Credibility” (unpublished; Stanford, California: Stanford University, Department of Economics).

Masson, Paul, and Catherine Pattillo, 2001, "Monetary Union in West Africa (ECOWAS)," IMF Occasional Paper No. 204 (Washington: International Monetary Fund).

Masson, Paul R., Miguel A. Savastano, and Sunil Sharma, 1997, “The Scope for Inflation Targeting in Developing Countries," IMF Working Paper 97/130 (Washington: International Monetary Fund).

McPherson, Charles P., 2002, "Petroleum Revenue Management in Developing Countries" (unpublished; Washington: World Bank).

Mishkin, Frederic S., 1991, "Asymmetric Information and Financial Crises: A Historical Perspective," in Financial Markets and Financial Crises, ed. by R. Glenn Hubbard (Chicago, Illinois: University of Chicago Press).

1997, "The Causes and Propagation of Financial Instability: Lessons for Policymakers," paper presented at Maintaining Financial Stability in a Global Economy, a symposium sponsored by the Federal Reserve Bank of Kansas City, Jackson Hole, Wyoming, August 28-30.

— , 2000, "Inflation Targeting in Emerging Market Countries," NBER Working Paper No. 7618 (Cambridge, Massachusetts: National Bureau of Economic Research). , and Klaus Schmidt-Hebbel, 2001, "One Decade of Inflation Targeting in the World: What do we Know and What do we Need to Know?” NBER Working Paper No. 8397 (Cambridge, Massachusetts: National Bureau of Economic Research).

Morandé, Felipe G., 2000, “A Decade of Inflation Targeting in Chile: Main Developments and Lessons," in Monetary Policy and Inflation Targeting in Emerging Economies: Proceedings of a Conference held in Jakarta, July 2000, ed. by Charles Joseph and Anton H. Gunawan (Jakarta: Bank Indonesia). 
Ojo, M.O., 1999, "The Role of the Autonomy of the Central Bank of Nigeria (CBN) in Promoting Macroeconomic Stability," CBN Economic \& Financial Review, Vol. 38 (1), pp. 1-18.

Orphanides, Athanasios, 2001, "Monetary Policy Rules, Macroeconomic Stability and Inflation: A View from the Trenches," Board of Governors of the Federal Reserve System, FEDS Working Paper No. 2001-62 (Washington: Board of Governors of the Federal Reserve System).

Poole, William, 1970, “Optimal Choice of Monetary Policy Instrument in a Simple Stochastic Macro Model,” Quarterly Journal of Economics (May), pp. 197-216.

_ 1999, “Is Inflation Too Low?” Federal Reserve Bank of St. Louis Review, Vol. 81 (July, August), pp. 3-10.

Schaechter, Andrea, Mark R. Stone, and Mark Zelmer, 2000, "Adopting Inflation Targeting: Practical Issues for Emerging Market Countries," IMF Occasional Paper No. 202 (Washington: International Monetary Fund).

Sims, Christopher A., 2003, "Limits to Inflation Targeting” (unpublished; Princeton, New Jersey: Princeton University).

Škreb, Marko, 1998, “A Note on Inflation,” in Moderate Inflation: The Experience of Transition Economies, ed. by Carlo Cottarelli and György Szapáry (Washington: International Monetary Fund and Budapest: National Bank of Hungary).

Standard Chartered, 2003, "The Africa Report, Africa Focus and Country Focus: Nigeria" (London: Standard Chartered).

Taylor, John B., 1993, "Discretion Versus Policy Rules in Practice," Carnegie-Rochester Conference Series on Public Policy, Vol. 39 (December), pp. 195-220.

— 2000a, "Recent Developments in the Use of Monetary Policy Rules," a presentation at the conference, Inflation Targeting and Monetary Policies in Emerging Economies, at the Central Bank of the Republic of Indonesia, Jakarta, July 13-14.

__ 2000b, "Using Monetary Policy Rules in Emerging Market Economies," paper presented at Banco de México's 75th Anniversary Seminar "Stabilization and Monetary Policy: The International Experience," Mexico City, November 14-15. 